\title{
Total OH reactivity measurements in Paris during the 2010 MEGAPOLI winter campaign
}

\author{
C. Dolgorouky ${ }^{1}$, V. Gros ${ }^{1}$, R. Sarda-Esteve ${ }^{1}$, V. Sinha ${ }^{2}$, J. Williams ${ }^{3}$, N. Marchand ${ }^{4}$, S. Sauvage ${ }^{5,6}$, L. Poulain ${ }^{7}$, \\ J. Sciare ${ }^{1}$, and B. Bonsang ${ }^{1}$ \\ ${ }^{1}$ Laboratoire des Sciences du Climat et de l'Environnement (LSCE), Unité Mixte CEA-CNRS-UVSQ (Commissariat à \\ l'Energie Atomique, Centre National de la Recherche Scientifique, Université de Versailles Saint-Quentin-en-Yvelines), \\ UMR8212, 91198 Gif-sur-Yvette, France \\ ${ }^{2}$ Indian Institute of Science Education and Research (IISER) Mohali, Sector 81 SAS Nagar, Manauli PO Punjab 140306, India \\ ${ }^{3}$ Max Planck Institute for Chemistry, Air Chemistry Department, 55128 Mainz, Germany \\ ${ }^{4}$ Aix-Marseille Université, CNRS, LCE FRE 3416, 13331, Marseille, France \\ ${ }^{5}$ Université de Lille Nord de France, 59000 Lille, France \\ ${ }^{6}$ Ecole de Mines Douai, Departement Chimie environnement, 59508 Douai, France \\ ${ }^{7}$ Leibniz - Institut für Troposphärenforschung (IFT), Leipzig, Germany \\ Correspondence to: V. Gros (valerie.gros@1sce.ipsl.fr)
}

Received: 16 February 2012 - Published in Atmos. Chem. Phys. Discuss.: 27 April 2012

Revised: 6 September 2012 - Accepted: 17 September 2012 - Published: 22 October 2012

\begin{abstract}
Hydroxyl radicals play a central role in the troposphere as they control the lifetime of many trace gases. Measurement of $\mathrm{OH}$ reactivity ( $\mathrm{OH}$ loss rate) is important to better constrain the $\mathrm{OH}$ budget and also to evaluate the completeness of measured VOC budget. Total atmospheric $\mathrm{OH}$ reactivity was measured for the first time in an European Megacity: Paris and its surrounding areas with 12 million inhabitants, during the MEGAPOLI winter campaign 2010. The method deployed was the Comparative Reactivity Method (CRM). The measured dataset contains both measured and calculated $\mathrm{OH}$ reactivity from $\mathrm{CO}, \mathrm{NO}_{\mathrm{x}}$ and VOCs measured via PTR-MS, GC-FID and GC-MS instruments. The reactivities observed in Paris covered a range from $10 \mathrm{~s}^{-1}$ to $130 \mathrm{~s}^{-1}$, indicating a large loading of chemical reactants. The present study showed that, when clean marine air masses influenced Paris, the purely local $\mathrm{OH}$ reactivity $\left(20 \mathrm{~s}^{-1}\right)$ is well explained by the measured species. Nevertheless, when there is a continental import of air masses, high levels of $\mathrm{OH}$ reactivity were obtained $\left(120-130 \mathrm{~s}^{-1}\right)$ and the missing $\mathrm{OH}$ reactivity measured in this case jumped to $75 \%$. Using covariations of the missing $\mathrm{OH}$ reactivity to secondary inorganic species in fine aerosols, we suggest that the missing $\mathrm{OH}$ reactants were most likely highly oxidized compounds issued from photochemically processed air masses of anthropogenic origin.
\end{abstract}

\section{Introduction}

The hydroxyl radical $(\mathrm{OH})$ represents the most important oxidant in the troposphere. It governs the atmospheric lifetime of most reactive trace species of anthropogenic and biogenic origin and contributes to the self-cleansing capacity of the atmosphere.

Budget of $\mathrm{OH}$ radical is still associated with large uncertainty. Although the source term is generally dominated by ozone photolysis, additional $\mathrm{OH}$ sources can also be significant, especially in a urban environment, such as photolysis from nitric acid or from various aldehydes as described in details in Michoud et al. (2012) and references therein. The lost processes, or sink tem, are also still poorly constrained. In most cases the overall sink term of $\mathrm{OH}$ radicals is estimated by the sum of the products of concentration and the rate coefficient of all individually measured species reactive to the $\mathrm{OH}$ radical. This method has proved to be rather limited due to the large number of "OH reactive" volatile organic compounds (VOCs) in urban air (Lewis et al., 2000; Xu et al., 2003). Recently, Goldstein and Galablly (2007) postulated that $10^{5}$ different VOCs have been detected in the Earth's atmosphere. Moreover, recent studies showed that there are unknown reactive species that contribute to the total $\mathrm{OH}$ reactivity (Di Carlo et al., 2004; Sinha et al., 2010; Kato et

Published by Copernicus Publications on behalf of the European Geosciences Union. 
al., 2011). The necessity of measuring the total sink of $\mathrm{OH}$ radicals, also called the $\mathrm{OH}$ reactivity $\left(\mathrm{s}^{-1}\right)$, has therefore become evident. Presently three different types of instruments exist for the direct measurement of the total $\mathrm{OH}$ reactivity. The LIF community has two versions depending on how they detect the decrease of $\mathrm{OH}$ in their reactor. The first method is based on the Laser Induced Fluorescence (LIF) technique which records the decay (loss rate) of the $\mathrm{OH}$ radicals. Two versions of instruments using LIF technique exist: one that measures the $\mathrm{OH}$ reactivity as the inverse of the atmospheric $\mathrm{OH}$ lifetime in a reaction flow tube with a movable $\mathrm{OH}$ injector (Kovacs and Brune, 2001; Mao et al., 2010; Ingham et al., 2009) the other one uses a laser pump and probe technique (Sadanaga et al., 2005). The second method is called the Comparative Reactivity Method (CRM) and is based on comparative $\mathrm{OH}$ reactivity measurement in a flow reactor against the known $\mathrm{OH}$ reactivity of an added reagent (e.g. pyrrole, $\mathrm{C}_{4} \mathrm{H}_{5} \mathrm{~N}$ ). CRM has been developed and described in detail by Sinha et al. (2008).

Total $\mathrm{OH}$ reactivity has been measured in different environments for the last decade. Lou et al. (2010) reported 18 studies conducted in urban, rural and forested areas. The urban areas investigated included studies over New York City (summer 2001 and winter 2004), Mexico City Metropolitan area (spring 2003), Tokyo (summer 2003, winter 2004), Houston (autumn 2000, autumn 2006), Nashville (summer 1999) and Mainz (summer 2008). The results of these studies are synthetized in Table 4 . The ranges of the $\mathrm{OH}$ reactivity registered in these urban areas went from $6 \mathrm{~s}^{-1}$, for the clean atmosphere of the small city of Mainz, Germany (Sinha et al., 2008) to $200 \mathrm{~s}^{-1}$, for the extremely polluted air of Mexico City (Shirley et al., 2006). More recently, Sinha et al. (2012) report measurements from El Arenosillo in Spain, where $\mathrm{OH}$ reactivity ranged from below detection limit in marine air masses up to $70 \mathrm{~s}^{-1}$ in continental air masses.

Studies from forested areas have identified high percentages of missing $\mathrm{OH}$ reactivities, obtained from the comparison between the measured and the calculated reactivity, (70\% in the tropical forest of Surinam, Sinha et al., 2008 and $50 \%$ in boreal forest in Finland, Sinha et al., 2010), but also in rural areas (50\% in a subtropical rural area in PRD of China, Lou et al., 2010). In contrast, missing OH reactivity studies in megacities reported relatively low levels of missing $\mathrm{OH}$ reactivity: maximums of $30 \%$ for New York 2004 and Tokyo 2003. If the studies showed that in the case of the forested areas, the "responsible compounds" of the missing $\mathrm{OH}$ reactivity were non-measured biogenic compounds, the question is still open for the origin of the missing $\mathrm{OH}$ reactivity in an urban area.

This paper presents the $\mathrm{OH}$ reactivity measurements by CRM method conducted in January-February 2010 within the framework of the EU project MEGAPOLI (http:// megapoli.dmi.dk), in the city of Paris and its surrounding region (called "Ile de France") with almost 12 million in- habitants, and which constitutes one of the few megacities in Europe.

The employed method (CRM) was previously described in only four other studies: Sinha et al. (2008), Sinha et al. (2010), Kim and al. (2011) (but this is a modified version and not strictly our method) and Sinha et al. (2012). All of these measurements were made in environments poor in $\mathrm{NO}$ emissions, as interferences dues to $\mathrm{OH}$ recycling via $\mathrm{NO}+\mathrm{HO}_{2}$ reactions at $\mathrm{NO}>5 \mathrm{ppbv}$ in the setup were reported. This is for the first time that the CRM method has been used to measure $\mathrm{OH}$ reactivity measurements in an urban area characterized by high levels of NO emissions, as Paris was identified as a city mainly impacted by traffic emissions (Vardulakis et al., 2002). Therefore, the initial part of the article presents the experimental setup and the quantification of interferences in the system used for the MEGAPOLI winter campaign 2010.

The geographical location of Paris - a relatively smallarea basin surrounded by rural areas - makes it a favourable place to study purely local $\mathrm{OH}$ reactivity levels emitted by a megacity when air masses come from the clean marine western sector, and to characterize the impact of the European contribution when air masses come from the eastern sector.

Within the MEGAPOLI framework a large number of compounds has been simultaneously measured during this campaign: $\mathrm{NO}_{\mathrm{x}}$ (sum of $\mathrm{NO}$ and $\mathrm{NO}_{2}$ ), carbon monoxide (CO), ozone $\left(\mathrm{O}_{3}\right)$, non-methane hydrocarbons (NMHCs) and oxygenated VOCs (OVOCs). We could therefore compare the observed $\mathrm{OH}$ reactivity with the calculated values, which were derived using the observed concentrations of the trace species.

\section{Experimental}

\subsection{Experimental setup and field deployment}

\subsubsection{Experimental setup}

The comparative reactivity method for measuring the total OH reactivity is described in detail by Sinha et al. (2008). A brief overview of the principle of the measurement is nevertheless presented here: firstly, a mixture of pyrrole $\left(\mathrm{C}_{4} \mathrm{H}_{5} \mathrm{~N}\right)$ and synthetic dry air is injected into the reactor. The concentration $\mathrm{C}_{1}$ of the pyrrole is monitored in the flow exiting the reactor by a Proton Transfer Reaction - Mass Spectrometer (PTR-MS). Secondly, the UV rays emitted by a mercury lamp produce $\mathrm{OH}$ radicals $([\mathrm{OH}]<$ [pyrrole] $)$ to react with pyrrole $\left(k_{\mathrm{Py}+\mathrm{OH}}=1.2 \times 10^{-10} \mathrm{~cm}^{3}\right.$ molecules ${ }^{-1} \mathrm{~s}^{-1}$, Atkinson et al., 1984). The pyrrole concentration registered now is $\mathrm{C}_{2}$. Next, the synthetic air is replaced with ambient air. The $\mathrm{OH}$ reactive species contained in the ambient air compete with pyrrole for the available $\mathrm{OH}$ radicals. This causes an increase in the pyrrole monitored concentration from $\mathrm{C}_{2}$ to $\mathrm{C}_{3}$. The three measured concentrations, $\mathrm{C}_{1}, \mathrm{C}_{2}$ and $\mathrm{C}_{3}$, allow the 
calculation of the total $\mathrm{OH}$ reactivity via the following equation based on competitive kinetics, which has been derived by Sinha et al. (2008).

$R_{\mathrm{air}}=\frac{\mathrm{C}_{3}-\mathrm{C}_{2}}{\mathrm{C}_{1}-\mathrm{C}_{3}} \cdot k_{\mathrm{Py}+\mathrm{OH}} \cdot \mathrm{C}_{1}$

The schematic diagram of the CRM measurement system deployed for the MEGAPOLI campaign is shown in Fig. 1. The glass reactor used for the MEGAPOLI winter campaign is identical in shape and dimension with the one described in Sinha et al. (2008).

To measure $\mathrm{C}_{1}, \mathrm{C}_{2}$ and $\mathrm{C}_{3}$, three different instrumental modules were used: the "synthetic air" module, the "nitrogen" module and the "ambient air" module (see Fig. 1). The "nitrogen" module is used to produce the $\mathrm{OH}$ radical via the UV photolysis of the water molecules imported by the humidified nitrogen bubbled through a pure water bottle. The same method to produce $\mathrm{OH}$ radicals has largely been used in the techniques of $\mathrm{OH}$ radical measurements (LIF measurements: Kovacs et al., 2003; Mao et al., 2009).

While switching from $\mathrm{C}_{1}$ to $\mathrm{C}_{2}$, the synthetic air entering the reactor is humidified via the "synthetic air" module. Two mass flow controllers (MFC A and MFC B on the Fig. 1) are used and two flows of a $100 \%$ humidified and dry zero air are mixed together. Their mixing proportion determines the humidity of the final zero air flow. The relative humidity of $\mathrm{C}_{2}$ baseline signal during MEGAPOLI was maintained constant at $50 \%$, for a temperature of $24^{\circ} \mathrm{C}$. For more details concerning the correction applied to the data set because of the difference in the humidity of the synthetic air and ambient air, the reader is referred to Sect. 2.2.2, OH reactivity quantifying tests.

When switching from $\mathrm{C}_{2}$ to $\mathrm{C}_{3}$, the "synthetic air" module is switched OFF and the "atmospheric air" module is then connected, via a 3 way valve. This module consists of a Teflon VOC pump (KNF), a Teflon micro valve and $1 / 4$ and 1/16 inch flow reducing Teflon tubing (see Fig. 1).

The used detector located in the exit of the reactor is a high sensitivity PTR-MS, from Ionicon Analytik, Austria. The PTR-MS technology has been firstly introduced in studies of atmospheric chemistry by Lindinger et al. (1998). For this campaign the main monitored compound is pyrrole which is detected at the mass $m / z=68$ a.m.u. Other studies showed that this detector is ideal for measuring pyrrole, as the protonated ion does not fragment (Sinha et al., 2008, 2009). Also this mass is known to be free of interferences. The explored calibration range of pyrrole concentrations that are measured is from 0.5 to $250 \mathrm{ppbv}$, but on field measurements were always higher than $10 \mathrm{ppbv}$. The instrumental precision is of $6 \%$ for 2 standard deviations $(2 \sigma)$. The humidity inside the reaction cell is important for accurate determination of the $\mathrm{OH}$ reactivity. To track the humidity into the reactor, the masses of the first two water clusters are also monitored: $\mathrm{m} / \mathrm{z}$ 37 (cluster $\mathrm{H}_{3} \mathrm{O}^{+} \mathrm{H}_{2} \mathrm{O}$ ) and $m / z 55$ (cluster $\mathrm{H}_{3} \mathrm{O}^{+}\left(\mathrm{H}_{2} \mathrm{O}\right)_{2}$ ),

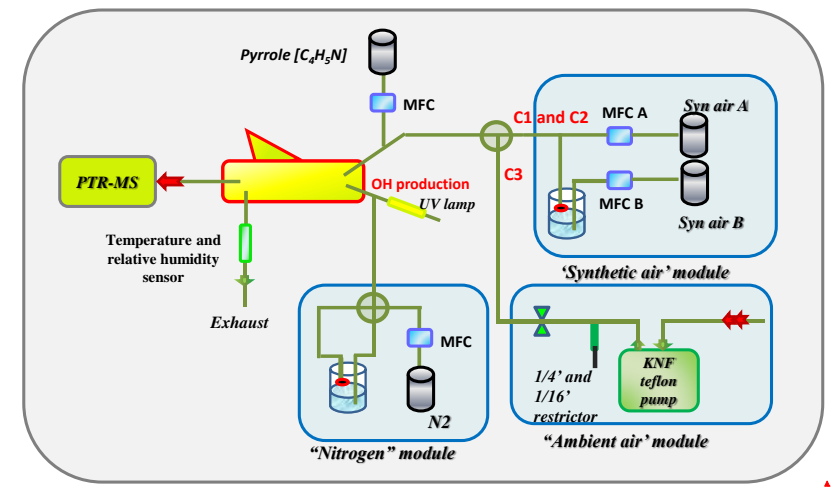

Fig. 1. OH reactivity system during MEGAPOLI winter 2010.

an approach described by Amman et al. (2006) and Sinha et al. (2008).

Besides the water cluster measurements that were used as proxies for the humidity into the reactor, an extra sensor for relative humidity and temperature was also installed in the exhaust line of the reactor (see Fig. 1). In contrast to the reactivity setup of Sinha et al. (2008) for the CRM used during the MEGAPOLI winter campaign, no other extra pump has been used at the exhaust line, the reactor being therefore maintained at ambient pressure with no over pressure inside the reactor.

\subsubsection{Field deployment}

The CRM system was deployed at the Laboratoire d'Hygiène de la Ville de Paris (LHVP) during the MEGAPOLI winter campaign 2010 (Fig. 2). The site is located in the heart of Paris (the 13th district) and therefore considered to be representative of the background pollution of central Paris.

The $\mathrm{OH}$ reactivity system was installed in a room where the temperature was maintained at $24^{\circ} \mathrm{C}$. The ambient air was sampled through a Teflon line of $1 / 4$ inch of diameter and a length of about $10 \mathrm{~m}$. The inlet was situated on the roof of LHVP, at a height of around 14 meters above the ground level. In order to avoid any particulate contamination, a 0.45 $\mu \mathrm{m}$ Teflon filter was used at the entrance of the sampling line. $\mathrm{OH}$ reactivity studies showed that the $\mathrm{OH}$ reactivity measurements are not influenced by the positioning of a Teflon filter in the entrance of the inlet line (Sadanaga et al., 2006).

Ambient air was then sampled at $150 \mathrm{ml} \mathrm{min}^{-1}$ in a total flow of $245 \mathrm{ml} \mathrm{min}^{-1}$ (dilution factor of the $\mathrm{OH}$ reactivity into the reactor of 1.65). The residence time of the compounds in the inlet lines was kept at $<35$ s by using a Teflon VOC sampling pump which draws a flow of $31 \mathrm{~min}^{-1}$. A $1 / 4$ inch and 1/16 inch flow-reducing Teflon tubes were used downstream to stabilize the ambient air flow into the reactor at $150 \mathrm{ml} \mathrm{min}^{-1}$ (see Fig. 1).

Atmospheric $\mathrm{OH}$ reactivity measurements were performed between 23 January and 13 February. The time resolution of 
the measurements was of $2 \mathrm{~min}$. Gaps in the data set were due to regular check-up of the instrument.

\subsection{Reactivity tests}

\subsubsection{Evaluation of the system}

At the beginning of the campaign, a series of tests were conducted from 8 to 23 January to characterize the system and the new reaction cell.

To check the accuracy of the CRM OH reactivity quantification, two standards have been used: a propane gas standard (Westfalen A.G.; $29.8 \mathrm{ppm}$ in $\mathrm{N}_{2}$; stated uncertainty $5 \%$ ) and a standard which was a mixture of 3 compounds in $\mathrm{N}_{2}$ : acetone, methanol and isoprene (Messer; $5.01 \mathrm{ppm}$ acetone, stated uncertainty $5 \% ; 6.78 \mathrm{ppm}$ methanol, stated uncertainty $5 \% ; 3.90 \mathrm{ppm}$ isoprene, stated uncertainty $10 \%$ ). The second standard has been analyzed in the laboratory in December 2009 prior to the MEGAPOLI campaign. Different quantities of standard have been introduced into the reactor. Using the definition of the $\mathrm{OH}$ reactivity, the reactivity due to the standard has been calculated via the equation:

$R_{\text {total }}=\sum k_{\text {compound }+\mathrm{OH}} \cdot[$ compound $]$

where the $k_{\text {compound }+\mathrm{OH}}$ represents the constant rate of each compound (propane, acetone, methanol and isoprene $)$ with the $\mathrm{OH}$ radical $\left(k_{\mathrm{OH}+\text { propane }}=1.1 \times 10^{-12} \mathrm{~cm}^{3}\right.$ molecule $\mathrm{s}^{-1} \mathrm{~s}^{-1}, k_{\mathrm{OH}+\text { acetone }}=1.8 \times 10^{-23} \mathrm{~cm}^{3}$ molecule ${ }^{-1}$ $\mathrm{s}^{-1}, k_{\mathrm{OH}+\text { methanol }}=7.65 \times 10^{-13} \mathrm{~cm}^{3}$ molecule ${ }^{-1} \mathrm{~s}^{-1}, k_{\mathrm{OH}+}$ isoprene $=1.0 \times 10^{-10} \mathrm{~cm}^{3}$ molecule $\mathrm{s}^{-1} \mathrm{~s}^{-1}$, Atkinson et al., 2006) and the [compound] is the concentration of the compound in molecules $\mathrm{cm}^{-3}$. Figure 3 presents the measured versus the calculated reactivity. The two standards allowed us to cover a range of $\mathrm{OH}$ reactivity from 3 to $50 \mathrm{~s}^{-1}$ for the propane standard, and a dynamic range comprised from 50 up to $300 \mathrm{~s}^{-1}$ for the acetone, methanol and isoprene standard. Corrections using the FACSIMILE model for deviations from the first order kinetics as described by Sinha et al. (2008) and for dilution of air in the reactor have already been applied.

The total uncertainty of the calculated reactivity is around $20 \%$ and comprises: uncertainty due to the rate coefficient of the standards with the $\mathrm{OH}$ radicals (18\%), flow fluctuations $(\sim 10 \%)$ and uncertainty due to the accuracy of the standards $(5 \%)$. The measured reactivity is obtained with the CRM (vertical axis). The total uncertainty for the measured reactivity is around $18 \%$ and comprises: uncertainty due to the rate coefficient of the pyrrole with the $\mathrm{OH}$ radicals $(13 \%)$, uncertainty of the standards (5\%), due to flow fluctuations $(10 \%)$ and the instrument precision $(2 \sigma, \sim 6 \%)$.

The calibration tests show a good linearity and accountability of the measured reactivity. The estimated detection limit of the ambient $\mathrm{OH}$ reactivity measurements within the setup is around $3 \mathrm{~s}^{-1}$.

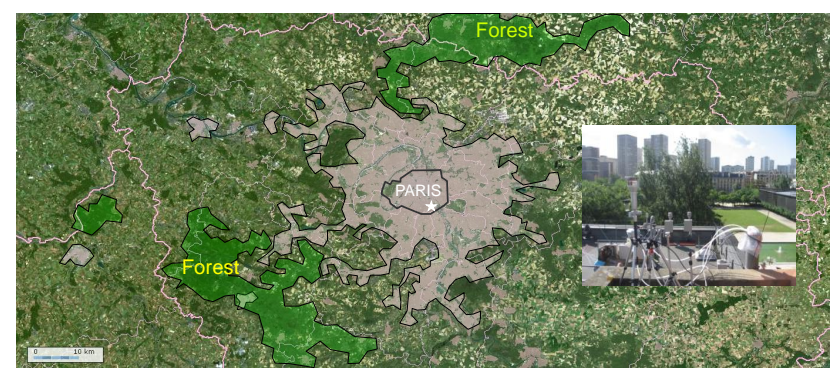

Fig. 2. Map of Paris and Ile de France region. The star locates the position of the LHVP laboratory. The picture shows the terrace roof of LHVP.

\subsubsection{OH reactivity quantifying tests}

As already identified by Sinha et al. (2008), interferences are potentially present in the setup. Photolysis of pyrrole is one of the possible interferences. Indeed the reactor is a turbulent flow reactor in which a which a flow of pyrrole and zeroair/ambient air mixes in with nitrogen at the mixing site right after the respective arms of the reactor (Fig. 1). While UV generation occurs within the arm, some rays from the $\mathrm{Hg}$ vapor lamp still enter the reactor, which is why a wood horn bulge was incorporated in the reactor design (see arm E of Fig. 2 in Sinha et al., 2008 and Fig. 1 of current work). The pen ray Hg lamp has emission lines at $184.9 \mathrm{~nm}$ (which photolyzes the water vapour), but also at $253.6 \mathrm{~nm}$. Pyrrole has been reported to absorb around the $253 \mathrm{~nm}$ wavelength (Bavia et al., 1976; Cronin et al., 2004) and hence to photolyze. The percentage of pyrrole photolysed in our setup is $19 \pm 2 \%$, but this does not influence our measurement because the Eq. (1) takes into consideration the real pyrrole concentration (after photolysis) available for reaction with the $\mathrm{OH}$ radicals ( $\mathrm{C} 1$ base line). No significant effect has been reported in previous studies from a potential secondary chemistry occurring in the reactor (due for example from radicals generated through the photolysis), as investigated in details by Sinha et al. (2008), Kim et al. (2011) and Noelscher et al. (2012).

\section{Humidity difference between the zero air and the ambient air}

Another potential interference is the humidity difference between the zero air and the ambient air. Different humidity conditions for the $\mathrm{C}_{2}$ and $\mathrm{C}_{3}$ signals correspond to different yields of $\mathrm{OH}$ radicals in the reactor, and therefore can lead to over or under estimation of the total $\mathrm{OH}$ reactivity. To avoid this, the humidity of the zero air must be kept the same as the one of the ambient air. In the experimental setup used during the winter 2010 MEGAPOLI campaign, the zero air was humidified to a constant value of $50 \%$. As the atmospheric humidity varied over the day, corrections were applied on the $\mathrm{C}_{2}$ base line signal so that the overall $\mathrm{OH}$ field stays constant. 


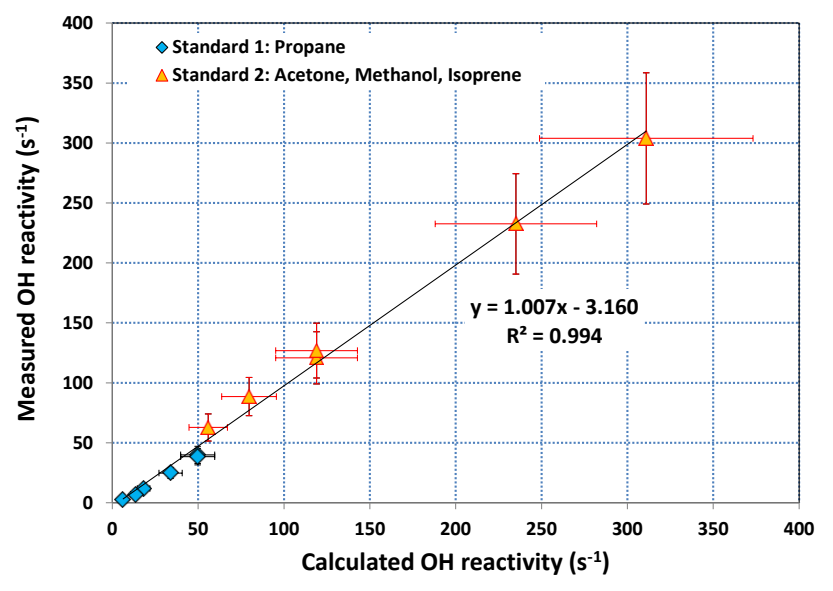

Fig. 3. Calibration results using two standards bottles: propane and acetone, methanol and isoprene standard. Error bars stand for estimated uncertainty on the measured and calculated $\mathrm{OH}$ reactivity (see text).

To do this, a "humidity test" was run. The zero air flowing into the reactor was humidified to different degrees by mixing varying amounts of wet and dry zero air, with the help of the "synthetic air" module presented in Fig. 1. The decrease in the pyrrole baseline $\left(\mathrm{C}_{2}\right)$ is then recorded for different relative humidities. During this test the mercury lamp is maintained $\mathrm{ON}$, as the purpose is the quantification of the real $\mathrm{OH}$ radical production into the setup. The humidity is tracked via the sensor installed on the exhaust line of the reactor and the results of this test are presented on Fig. 4.

A humidity correction has been applied based on this test on the $\mathrm{C}_{2}$ baseline signal. Note that while this correction may seem significant ( $\sim$ up to $30 \%$ ), as the ambient air was more humid than zero air, it would only cause underestimation of the true $\mathrm{OH}$ reactivity thus leave conclusions of the paper regarding missing $\mathrm{OH}$ reactivity robust and intact.

The test revealed that for a relative humidity of between $60-70 \%$, the setup is much more sensitive to a change in the pyrrole signal than for humidity comprised between 80 and $90 \%$ (the slope being smaller). Therefore, if there is no possibility of regulating the humidity of the $\mathrm{C}_{2}$ signal to the one of the $\mathrm{C}_{3}$ signal, as in the present work, it is advised to keep the total relative humidity of the $\mathrm{C}_{2}$ base line signal in the ranges of 80 to $90 \%$.

\section{NO interference into the setup}

As has been shown previously (Sinha et al., 2008), for high values of the $\mathrm{NO}$ into the setup, secondary production of $\mathrm{OH}$ radicals is observed due to the recycling of the $\mathrm{HO}_{2}$ radicals. This interference is non-negligible for measurements made during the MEGAPOLI winter campaign, as the NO atmospheric levels went up to $100 \mathrm{ppb}$ during the morning rush hour (see top panel from Fig. 7). To overcome this potential

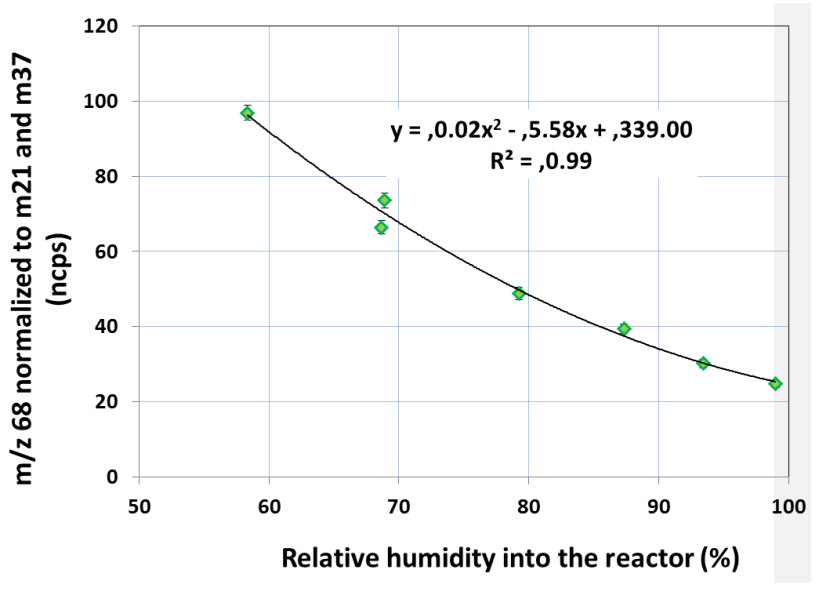

Fig. 4. Change in the pyrrole signal $(m / z$ 68) for different percentage of relative humidity into the setup. The temperature of the setup is maintained constant at $24^{\circ} \mathrm{C}$.

interference, firstly, the $\mathrm{NO}$ effect on the $\mathrm{OH}$ reactivity was quantified. Afterwards, a correction factor was applied to the ambient $\mathrm{OH}$ reactivity.

For the quantification of the NO interference, different amounts of NO were injected into the reactor and the decrease of the pyrrole signal due to additional $\mathrm{OH}$ radicals, recycled via the $\mathrm{HO}_{2}+\mathrm{NO} \rightarrow \mathrm{OH}+\mathrm{NO}_{2}\left(k_{\mathrm{HO}_{2}+\mathrm{NO}}=8.8 \times\right.$ $10^{-12} \mathrm{~cm}^{3}$ molecule $\mathrm{s}^{-1} \mathrm{~s}^{-1}$, Atkinson et al., 2004) reaction, was analysed. The result of the test is presented in the Fig. 5, where the absolute change in the measured $\mathrm{OH}$ reactivity was plotted against the NO values in the setup.

The test was run for an initial $\mathrm{OH}$ reactivity of $50 \mathrm{~s}^{-1}$ (using the propane standard described previously) and showed a change in the slope at NO value of $20 \mathrm{ppbv}$. A secondary NO test was made 2 weeks later with no propane injected into the reactor $(\mathrm{OH}$ reactivity null). This secondary test was not presented on Fig. 5, but again, the change in the slope was noted for NO of $20 \mathrm{ppbv}$ into the setup. Two different slopes were therefore considered for correction of the ambient $\mathrm{OH}$ reactivity.

The vertical axis uncertainty was $20 \%$ and corresponded to the total $\mathrm{OH}$ reactivity uncertainty as quantified for the calibration tests described in Sect. 2.2.1. The total horizontal uncertainty was $11 \%$, and took into consideration NO flow fluctuations $(10 \%)$ and the uncertainty of the NO standard $(5 \%)$.

For the MEGAPOLI winter campaign, the $\mathrm{OH}$ reactivity data set was corrected for the NO interference as follows: for $\mathrm{NO}$ values into the setup smaller than $20 \mathrm{ppbv}$ (equivalent to ambient NO concentration of $33 \mathrm{ppbv}$, for a dilution factor into the reactor of 1.65), the measured $\mathrm{OH}$ reactivity was increased with a value equivalent of the product between the 1st slope determined $\left(1.13 \mathrm{~s}^{-1} \mathrm{ppbv}^{-1}\right)$ and the measured $\mathrm{NO}$ value into the setup. For NO values higher than $20 \mathrm{ppbv}$, the measured $\mathrm{OH}$ reactivity was increased with the $0.46 * \mathrm{NO}$ 


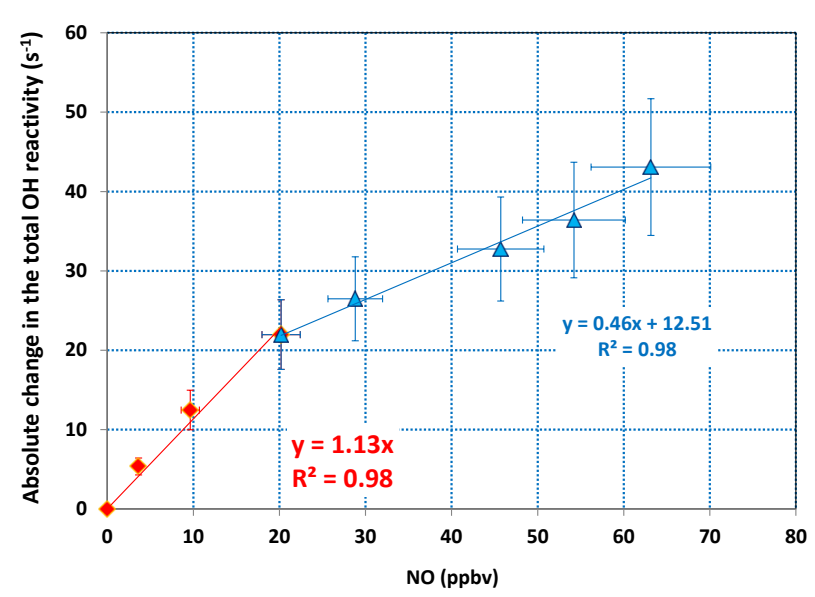

Fig. 5. NO test for $\mathrm{OH}$ reactivity of $50 \mathrm{~s}^{-1}$ : the red and the blue curves represent the 2 different slopes obtained for values of NO smaller or bigger than 20 ppbv.

concentration $+12.51 \mathrm{~s}^{-1} .99 \%$ of the $\mathrm{OH}$ reactivity dataset corresponds to the first regime (NO $<20 \mathrm{ppbv}$ ) and only $1 \%$ to the second regime $(\mathrm{NO}>20 \mathrm{ppbv})$.

\section{Frequency of the $C_{0}, C_{1}$ and $C_{2}$ signal measurements}

No $\mathrm{C}_{1}$ measurements were completed between 23 and 30 January, being replaced by $\mathrm{C}_{0}$ measurements. These measurements correspond to measurements made in the same conditions as $\mathrm{C}_{1}$ with the UV lamp turned OFF. The photolytic loss of pyrrole described by the difference between $\mathrm{C}_{0}$ and $\mathrm{C}_{1}$ signals is an indicator of the stability of the emission rays of the lamp, and therefore of the constant $\mathrm{OH}$ field production into the reactor. The photolytic loss for different $\mathrm{COs}$ was quantified at the beginning and during the campaign as follows: from 8 to 23 January and after 31 January. The results indicated a constant photolytic loss of $19 \pm 2 \%$ over the entire period. The missing $\mathrm{C}_{1}$ levels were therefore confidently quantified based on the correspondent $\mathrm{C}_{0}$ levels.

The CRM method is based on the comparison between the $\mathrm{C}_{2}$ and $\mathrm{C}_{3}$ signals and therefore frequent measurements of the $\mathrm{C}_{2}$ signal are required. During the MEGAPOLI winter campaign, the $\mathrm{C}_{2}$ baseline signal was determined 2 to 3 times per day. Although not very frequently measured, the variability of the $\mathrm{C}_{2}$ showed a daily variation of maximum $15 \%$ over the entire campaign. An additional error of $15 \%$ due to extrapolating successive baselines was therefore considered to the total uncertainty of the measured $\mathrm{OH}$ reactivity. A total uncertainty of $24 \%$ was finally considered for the measured $\mathrm{OH}$ reactivity values during the MEGAPOLI campaign. This result comprises: uncertainty due to the rate coefficient of the pyrrole with the $\mathrm{OH}$ radicals $(13 \%)$, uncertainty of the standard $(5 \%)$, due to flow fluctuations $(6 \%)$, the instrument precision $(2 \sigma, \sim 6 \%)$ and the uncertainty due to low frequency $\mathrm{C}_{2}$ measurements $(15 \%)$.

\subsection{Ancillary measurements at LHVP site during MEGAPOLI winter campaign}

Within the MEGAPOLI framework, additional measurements of $\mathrm{CO}, \mathrm{NO}_{\mathrm{x}}$, non-methane hydrocarbons (NMHCs) and oxygenated volatile organic compounds (OVOCs), as well as aerosol chemical composition were also performed. All sampling lines from VOC instruments were on the roof of LHVP, within a few meters of the $\mathrm{OH}$ reactivity sampling line.

Ozone was measured with an analyzer based on UV absorption (41M, Environnement SA) and nitrogen oxides were measured by chemiluminescence with an AC31M analyzer (Environnement SA). CO was measured by an analyzer based on IR absorption (48i-TL instrument, Thermo Electron Corporation, Waltham, MA, USA). More details for these instruments are given in Gros et al. (2011).

\subsubsection{Non-methane hydrocarbon on-line measurements by gas chromatography}

Two portable gas chromatographs equipped with a flame ionization detector (GCFID, Chromatotec, Saint Antoine, France) were used to measure non-methane hydrocarbons (NMHC) in ambient air. The first analyser, ChromaTrap, allowed the measurement of $\mathrm{C}_{2}-\mathrm{C}_{6}$ hydrocarbons and the second, AirmoBTX, the measurement of $\mathrm{C}_{6}-\mathrm{C}_{10}$ hydrocarbons. As the same instruments were used for atmospheric measurements during the spring 2007 Paris campaign, their technical information (type of columns, sampling flows, preconcentration, desorption-heating temperatures and times, etc.) was already described in details by Gros et al. (2011).

For both GC instruments, the sampling time was $10 \mathrm{~min}$ and analysis time was $20 \mathrm{~min}$, and therefore measurements were performed with a time resolution of $30 \mathrm{~min}$.

\subsubsection{VOC measurements by PTR-MS}

HS-PTRMS (High Sensitivity Proton Transfer Reaction Mass Spectrometer, Ionicon Analytic, Lindinger et al., 1998) was deployed during the intensive field campaign in order to quantify VOCs and oxygenated VOCs. The sampling line consisted of $10 \mathrm{~m}$ Teflon tubing. A primary flow of $101 \mathrm{~min}^{-1}$ was maintained in the sampling line. During the campaign $39 \mathrm{~m} / \mathrm{z}$ were monitored in the SIM mode with a temporal resolution of $2.5 \mathrm{~min}$. These ions include $\mathrm{m} / \mathrm{z}$ $=25,32,37,39,55,80$ used to control the PTRMS performances (fragmentation, ionization) and the 33 remaining $m / z$ correspond to individual VOC's or sum of isomers. Within this study 5 VOC's measured by PTRMS were considered: benzene $(m / z=79)$, toluene $(m / z=93)$, acetonitrile $(m / z=42)$, methanol $(m / z=33)$ and acetaldehyde $(m / z=45)$. Transmission of the PTR-MS quadrupole were adjusted by the mean of 18 individual VOCs with certified concentration overlapping the mass range of the VOCs 
monitored within the field campaign. The 5 selected VOCs were also individually calibrated in the range $0.2-8 \mathrm{ppb}$ at $50 \% \mathrm{RH}$.

\subsubsection{Oxygenated compounds measurements by GC-MS}

For OVOC measurements, air sampling was performed at 15

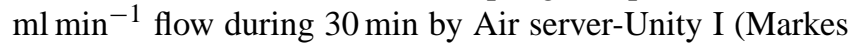
International, Llantrisant, UK). After sampling, the compounds were then thermally desorbed and injected through a transfer line into a high polar column and analyzed by GC (Agilent, Massy, France) equipped with a FID and a Mass Spectrometer. This device allowed the identification and the quantification of 19 OVOC and $11 \mathrm{NMHC}$ from $\mathrm{C}_{2}$ to $\mathrm{C}_{9}$ with a time resolution of $1.5 \mathrm{~h}$. Technical precisions are given by Roukos et al. (2009).

\subsubsection{Fine aerosol measurements by AMS}

A suite of instrumentation for the characterization of the physico-chemical properties of particles was deployed in the garden of the LHVP building (approx. $14 \mathrm{~m}$ below the sampling line of the $\mathrm{OH}$-reactivity system). The instruments included a High Resolution Time-of-Flight Aerosol Mass Spectrometer (HR-ToF-AMS), here simply referred to as AMS, Aerodyne Research Inc., DeCarlo et al. (2006). A collection efficiency of 0.4 was calculated for the HR-ToF-AMS based on comparison with concurrent TDMPS and particleinto-liquid sampler (PILS) data (Healy et al., 2011). All instruments were connected to the same sampling system consisting of a $\mathrm{PM}_{10}$ inlet located approximately $6 \mathrm{~m}$ above ground level directly followed by an automatic aerosol diffusion dryer system maintaining the relative humidity in the line below $30 \%$ Tuch et al. (2009).

The AMS was operated at $5 \mathrm{~min}$ time resolution. Due to the $600^{\circ} \mathrm{C}$ surface temperature of the vaporizer, the AMS can only measure the non-refractory (NR) part of the particles (ammonium, nitrate, chloride, sulphate, and organic matter). Therefore, based on the aerodynamic lenses transmission efficiency and the detected compounds, AMS results are commonly considered to correspond to the non-refractory PM1 aerosol (NR-PM1) Canagaratna et al. (2007).

\subsection{Description of the FLEXPART model}

The FLEXPART model represents a quantitative dispersion model which takes into consideration turbulence, convection parameterizations, dry and wet deposition to do backwards calculations from a measurement site (receptor) for the volume mixing ratio of a generic inert tracer with infinite lifetime. The generic inert tracer consists of 40000 particles released in a small box at the measurement location and during the measurement interval $(3 \mathrm{~h})$ and followed backward in time for 20 days. The model output unit is called PES, acronym from "potential emission sensitivity" distribution.
The unit of the PES is in $\mathrm{s} \mathrm{kg}^{-1}$ and its value in a particular grid (geographical place) is proportional to the particle residence time in that cell. It is a measure for the simulated mixing ratio at the receptor that a source of unit $\left(1 \mathrm{~kg} \mathrm{~s}^{-1}\right)$ in the respective grid cell would produce. For more details on the way that the model works, the reader is sent to the FLEXPART descriptive paper of Stohl et al. (2005).

\section{Results and discussion}

In order to understand the $\mathrm{OH}$ reactivity results, a short description of the air masses impacting the site and a brief discussion on the pollution levels registered in Paris during the MEGAPOLI winter campaign are presented as follows.

\subsection{Air mass origins during MEGAPOLI}

$\mathrm{OH}$ reactivity measurements were made from 23 January until 13 February. During this time, a wide variety of air masses passed over Paris and its surroundings. In the Supplement of the article, all of these air masses are synthesized along with their origins (see Appendix A), as represented by the 20 days back trajectories calculated with the FLEXPART model.

We have chosen for discussion in this paper three contrasting periods characterising different regimes in the $\mathrm{OH}$ reactivity measurements. The corresponding backward trajectories are given in Fig. 6. The first period (hereafter called "period I") starts with 26 January, 03:00, and ends on 27 January, 21:00 LT. This period corresponded to air masses originating from the eastern part of Europe, passing firstly over the Benelux area and in the second part of this period over Germany.

The second period (hereafter called "period II") started on 2 February, 09:00, and ended on 4 February, 03:00. In this period, clean air masses originating from the Atlantic Ocean arrived over Paris.

The third period (hereafter called "period III") started with 9 February, 18:00, and lasted until the end of the campaign, 13 February, 16:00. The air masses originated again from the northern part of the continent, passing over Germany before joining Paris.

In conclusion, periods I and III were therefore characterized as "continental air masses", while period II was characterized as "oceanic air masses".

\subsection{Air quality in Paris during MEGAPOLI}

\subsubsection{Ambient levels of VOCs in Paris - comparison to levels observed in other urban environments}

The median values of the main gas tracers recorded in Paris over the entire MEGAPOLI winter campaign were: $300 \pm 98 \mathrm{ppbv}$ for $\mathrm{CO}, 27 \pm 11 \mathrm{ppbv}$ for $\mathrm{NO}_{2}$ and $13 \pm 8 \mathrm{ppbv}$ for ozone $\left(\mathrm{O}_{3}\right)$. NO presented a high variability during this period: a mean value of $10 \mathrm{ppbv}$ and a median of $5.5 \mathrm{ppbv}$. 


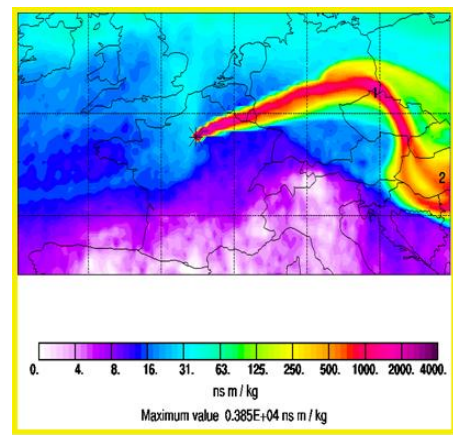

(a) Period I

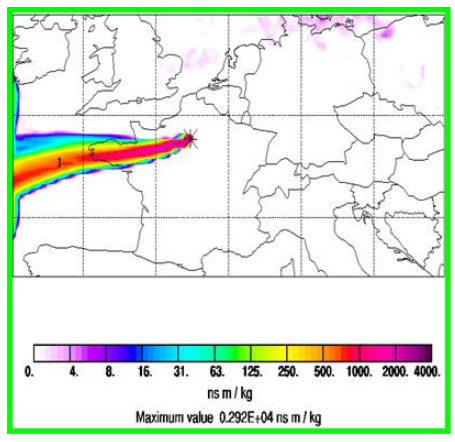

(b) Period II

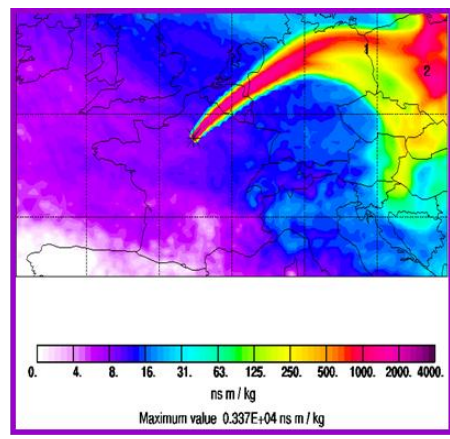

(c) Period III

Fig. 6. Backward trajectories characterizing the air masses of the three contrasted $\mathrm{OH}$ reactivity periods (a) continental air masses on 27 January, (b) ocean air masses on the 3rd of February and (c) continental air masses on 9 February Source: FLEXPART model (see text).

Previously a campaign has been conducted in Paris during spring 2007 (Gros et al., 2007) and a brief comparison with the pollutant levels is given on the same site as the MEGAPOLI winter campaign 2010. The median values corresponding to $\mathrm{CO}, \mathrm{NO}, \mathrm{NO}_{2}$ and $\mathrm{O}_{3}$ measured during spring 2007 were $248 \pm 80 \mathrm{ppbv}$ for $\mathrm{CO}, 4.4 \pm 1.6 \mathrm{ppbv}$ for $\mathrm{NO}, 11.2 \pm 7.4 \mathrm{ppbv}$ for $\mathrm{NO}_{2}$ and $26 \pm 13 \mathrm{ppbv}$ for $\mathrm{O}_{3}$. It can be seen that higher levels of $\mathrm{CO}, \mathrm{NO}$ and $\mathrm{NO}_{2}$ were registered during MEGAPOLI 2010 than for the 2007 campaign, and this is likely because of the higher anthropogenic emissions expected during the cold season. Because of a lower photochemical activity during winter, the $\mathrm{O}_{3}$ level measured during MEGAPOLI 2010 campaign was lower than in spring 2007.

A brief comparison between the pollution levels reported from several cities where $\mathrm{OH}$ reactivity measurements are available is presented in Table 1. These cities were: Houston, New York, Mexico City, Tokyo and Paris. The background and the maximum registered levels of $\mathrm{CO}, \mathrm{NO}_{\mathrm{x}}, \mathrm{O}_{3}$ and the sum of non-methane hydrocarbons (NMHC) are summarized. The periods of the year when the measurements were done and the total population of the Metropolitan Areas were also presented. The most populated city was Tokyo with 36 million inhabitants, followed by New York and Mexico City, each of 22 million inhabitants. Paris and its surrounding area, called Ile de France, counted for 12 million inhabitants, representing one of the few megacities in Europe. Among the studied cases, Tokyo $\left(36^{\circ} \mathrm{N}, 140^{\circ} \mathrm{E}\right)$ presented measurements in winter, in the same period when the measurements of Paris were realized. As Tokyo is at about $35^{\circ} \mathrm{N}$ one may expect the winter effect of more emissions to be less pronounced.

The measured levels of the compounds presented in the Table 1 correspond to median daily values. The background values correspond to midnight median levels, while the maximums represent the maximum registered of the median daily values. For more details on the measured data for Houston,
New York and Mexico City, the reader is sent to Shirley et al. (2006) and Mao et al. (2009) and references therein. For Tokyo measurements, see Yoshino et al. (2006).

In terms of carbon monoxide, the background levels measured in Paris are generally lower than values measured in the other cities. In winter, Tokyo registered a maximum of CO 3 to 4 times higher than the Paris maximum, but 2 times lower than the maximum observed for Mexico-City. Nevertheless, the maximum level of $\mathrm{CO}$ in Paris measured in the cold season remains comparable to maximums observed in New York City and Houston, though smaller and for different periods.

In terms of $\mathrm{NO}_{\mathrm{x}}$, the Paris background is slightly higher than the background levels measured in the other cities. Nevertheless, the maximum value remains comparable to the values measured in New York City and Tokyo (in summer and in autumn), but still almost two times lower than the maximum registered for the Mexico City in spring season and Tokyo in winter season. This is a comparison only on levels and does not consider inter annual variation of this pollutant concentration.

Generally, the Paris background level of NMHC sum was two times lower than in New York and Houston, 2000. The maximum is being $30 \%$ to $50 \%$ lower than those of New York and Houston, 2000 respectively. The high values in the sum of the NMHC measured for Houston in 2006 were mainly due to spikes at night correlated to emission events from plants in the Houston Ship Channel (Day et al., 2010). Greater discrepancies were nevertheless noted with respect to Mexico City when both the background and the maximum levels were 10 times higher than in Paris.

This quick comparative analysis allowed us to conclude that Paris presents intermediate levels of gaseous pollutants $\left(\mathrm{CO}, \mathrm{NO}_{\mathrm{x}}, \mathrm{NMHC}\right)$, between medium size cities (Houston) and megacities like Tokyo, New York and Mexico City. This is explained by its smaller population and its less industrialized character. 
Table 1. Gaseous pollutants levels registered in different urban atmospheres.

\begin{tabular}{|c|c|c|c|c|c|c|c|c|c|c|}
\hline & $\begin{array}{l}\text { Population }{ }^{\mathrm{a}} \text { in } \\
2010\left(10^{\wedge} 6\right)\end{array}$ & $\begin{array}{l}\text { Period of } \\
\text { the year }\end{array}$ & $\begin{array}{l}\text { CO BGND } \\
\text { level (ppbv) }\end{array}$ & $\begin{array}{l}\text { CO max } \\
(\mathrm{ppbv})\end{array}$ & $\begin{array}{l}\mathrm{NO}_{\mathrm{x}} \text { BGND } \\
\text { levels (ppbv) }\end{array}$ & $\begin{array}{l}\mathrm{NO}_{\mathrm{x}} \\
\max (\mathrm{ppbv})\end{array}$ & $\begin{array}{l}\text { Ozone BGND } \\
\text { level (ppbv) }\end{array}$ & $\begin{array}{l}\text { Ozone } \\
\max (p p b v)\end{array}$ & $\begin{array}{l}\text { NMHC } \\
\text { BGND (ppbv) }\end{array}$ & $\begin{array}{l}\text { NMHC } \\
\max (p p b v)\end{array}$ \\
\hline Houston & 6 & Aug-Sep 2000 & 200 & 250 & 5 & 22 & 25 & 70 & $100^{\mathrm{c}}$ & $200^{\mathrm{c}}$ \\
\hline New York City & 22 & Jun-Aug 2001 & 400 & 450 & 25 & 50 & 20 & 50 & $100^{\mathrm{c}}$ & $150^{\mathrm{c}}$ \\
\hline Mexico City & 22 & Apr 2003 & 100 & 3000 & 20 & 110 & 25 & 125 & $500^{\mathrm{c}}$ & $1000^{\mathrm{c}}$ \\
\hline Houston & 6 & Aug-Sep 2006 & 200 & 250 & 8 & 25 & 25 & 70 & $400^{c}$ & $750^{c}$ \\
\hline Tokyo & $36^{\mathrm{b}}$ & Jan-Feb 2004 & $400^{d}$ & $1200^{\mathrm{d}}$ & $25^{\mathrm{d}}$ & $105^{d}$ & $10^{\mathrm{d}}$ & $40^{d}$ & NA & NA \\
\hline Tokyo & $36^{\mathrm{b}}$ & May 2004 & $300^{\mathrm{d}}$ & $550^{\mathrm{d}}$ & $13^{\mathrm{d}}$ & $50^{\mathrm{d}}$ & $50^{\mathrm{d}}$ & $80^{\mathrm{d}}$ & NA & NA \\
\hline Tokyo & $36^{\mathrm{b}}$ & Nov 2004 & $400^{d}$ & $1000^{\mathrm{d}}$ & $20^{\mathrm{d}}$ & $65^{\mathrm{d}}$ & $10^{\mathrm{d}}$ & $60^{d}$ & NA & NA \\
\hline \multirow[t]{2}{*}{ Paris } & 12 & Jan-Feb 2010 & 250 & 350 & 30 & 60 & 15 & 17 & 12 & 17 \\
\hline & & & & & & & & & $50^{\mathrm{c}}$ & $100^{\mathrm{c}}$ \\
\hline
\end{tabular}

${ }^{a}$ Cities and Metropolitan Areas; ${ }^{\mathrm{b}}$ 2007; ${ }^{\mathrm{c}}$ values in ppbC (ppbCarbon); ${ }^{\mathrm{d}}$ daily mean values were taken into consideration when median diurnal cycles were not available; BGND: corresponds to background levels measured at midnight, local time;

NA: Non Available Data.

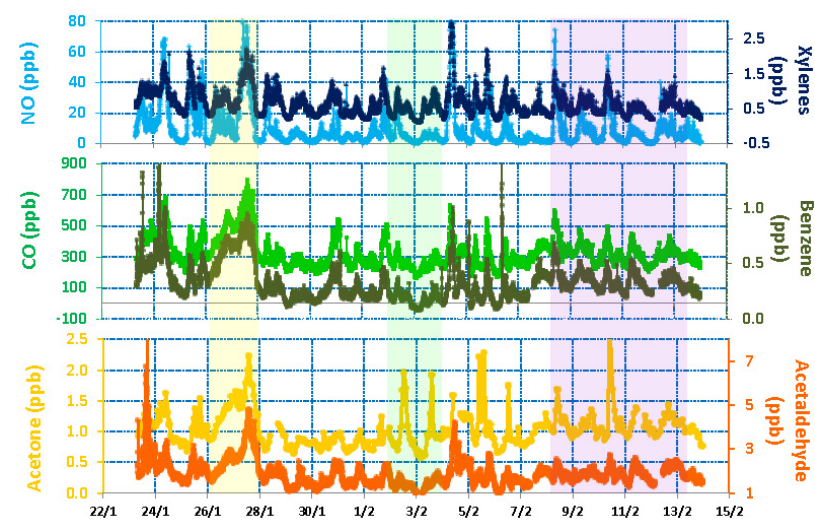

Fig. 7. Campaign time series: top panel: NO in light-blue solid line and the sum of xylenes in dark-blue solid line; 2nd panel: $\mathrm{CO}$ in light-green solid line and benzene in dark-green solid line; 3rd panel: acetone in light-orange solid line and acetaldehyde in darkorange solid line. The three air mass periods are colored as follows: in yellow the Period I, in green, Period II, and in violet, Period III.

Examining now the speciated VOCs measured during the MEGAPOLI winter campaign, Table 2 gives their mean and range over the measurement period. Some compounds (ex. Benzene, Toluene) were measured by several instruments and measurements from the instrument with the better time resolution were selected. Their corresponding $\mathrm{OH}$ reactivity, calculated as the product between the concentration and the equivalent reaction rate constant (Kovacs and Brune, 2001; Kovacs et al., 2003; Sadanaga et al., 2005; Mao et al., 2009, 2010) is also given and will be discussed in Sect. 3.4.

Alkanes, alkenes-alkynes (and isoprene, though usually under the detection limits, because of the cold season), aromatics and the oxygenated compounds accounted for 26,19 , 7 and $48 \%$ respectively of the total volume mixing ratio of the measured VOCs. The oxygenated VOCs contribute a large part to the total concentration of the compounds measured during the campaign. Among the oxygenated species, ethanol by itself accounted for more than half $(56 \%)$ to the total OVOC concentration, followed by the sum of methanol and acetaldehyde $30 \%$, and acetone with $8 \%$.

VOC source apportionment analysis was conducted by Gaimoz et al. (2011) for the spring 2007 campaign, allowing the characterization of the local pollution in Paris. The term "local pollution" means pollution from Paris and "Ile de France". The main source identified for VOC was traffic emission (fuel exhaust and evaporation) contributing to $50 \%$. Other contributing sources included natural gas emissions, background input and biogenic emissions.

\subsubsection{VOC variability: influence of local sources versus long-range transport}

To characterize the air quality of Paris during the MEGAPOLI winter campaign, the variability of specific compounds showing different sources and atmospheric lifetimes were analyzed. The three panels of the Fig. 7 present selected compounds and a discussion on their variability, sources and their relation to the air mass origin is given afterwards.

In the upper panel of Fig. 7, nitrogen oxide and the sum of $o, m$ and $p$ xylenes are presented. The baseline levels of these two anthropogenic and short life-time (a few hours) compounds do not seem to be significantly influenced by the different origins of the air masses. Secondly, as previously presented, the NO represents a typical marker of the traffic exhaust emissions. The covariation of the xylenes with the NO suggests that the xylenes' variability (but also that of other aromatic compounds, like toluene) in Paris was mainly controlled by the traffic source. This finding is in agreement with the conclusions from Gaimoz et al. (2011) (see Sect. 3.2.1).

The second panel presents two anthropogenic compounds with longer lifetimes: $\mathrm{CO}$ and benzene. $\mathrm{CO}$ represents a combustion tracer, having fossil fuel and biomass burning as primary sources. Its atmospheric life-time is relatively long, $\sim 2$ month (Crutzen, 1994). Benzene has a lifetime of about 6 days (for an $\mathrm{OH}$ concentration of $1.5 \times 10^{6}$ molecules $\mathrm{cm}^{-3}$, Seinfeld and Pandis, 2006) and its emissions in Paris are, like other aromatic compounds, linked to traffic activities. Both 
Table 2. Mean values of the main volatile-organic-compounds (VOC) volume mixing ratio measured during the campaign (TMB, trimethylbenzene; MVK, methyl vinyl ketone).

\begin{tabular}{|c|c|c|c|c|c|}
\hline Compound & $\begin{array}{l}\text { Measurement } \\
\text { technique }\end{array}$ & $\begin{array}{r}\text { Mean } \\
(\mathrm{ppbv})\end{array}$ & $\begin{array}{r}\text { Min } \\
(\mathrm{ppbv})\end{array}$ & $\begin{array}{r}\operatorname{Max} \\
(\mathrm{ppbv})\end{array}$ & $\begin{array}{l}\text { OH reactivity } \\
\qquad\left(\mathrm{s}^{-1}\right)\end{array}$ \\
\hline Ethane & GC-FID & 2.45 & 1.14 & 7.12 & 0.015 \\
\hline Ethene & GC-FID & 2.61 & 0.33 & 8.36 & 0.547 \\
\hline Propane & GC-FID & 2.12 & 0.76 & 5.04 & 0.057 \\
\hline Propene & GC-FID & 0.44 & 0.07 & 1.67 & 0.323 \\
\hline i-Butane & GC-FID & 0.91 & 0.15 & 2.84 & 0.052 \\
\hline n-Butane & GC-FID & 1.54 & 0.34 & 5.03 & 0.087 \\
\hline Acetylene & GC-FID & 1.77 & 0.62 & 5.04 & 0.044 \\
\hline 1-Butene & GC-FID & 0.09 & 0.02 & 0.26 & 0.093 \\
\hline i-Butene & GC-FID & 0.19 & 0.02 & 0.55 & 0.306 \\
\hline c-2-Butene & GC-FID & 0.05 & 0.02 & 0.53 & 0.080 \\
\hline trans-2-Butene & GC-FID & 0.07 & 0.01 & 0.23 & 0.126 \\
\hline Isoprene & GC-FID & 0.17 & 0.05 & 1.43 & 0.423 \\
\hline n-Hexane & GC-FID & 0.14 & 0.01 & 1.34 & 0.019 \\
\hline n-Pentane & GC-FID & 0.40 & 0.07 & 1.39 & 0.040 \\
\hline Benzene & PTR-MS & 0.33 & 0.08 & 1.65 & 0.010 \\
\hline Toluene & PTR-MS & 0.54 & 0.09 & 2.36 & 0.079 \\
\hline Xylenes & GC-FID & 0.67 & 0.13 & 2.88 & 0.265 \\
\hline TMB & GC-FID & 0.29 & 0.08 & 0.76 & 0.289 \\
\hline Acetonitrile & PTR-MS & 0.55 & 0.09 & 3.69 & 0.000 \\
\hline i-Propanol & GC-MS & 0.24 & 0.04 & 1.06 & 0.031 \\
\hline Ethanol & GC-MS & 7.68 & 2.22 & 23.57 & 0.605 \\
\hline MVK & GC-MS & 0.09 & 0.02 & 0.44 & 0.042 \\
\hline Acetone & GC-MS & 1.05 & 0.58 & 2.97 & 0.005 \\
\hline 2-Butanone & GC-MS & 0.29 & 0.06 & 0.94 & 0.009 \\
\hline Hexanal & GC-MS & 0.09 & 0.01 & 0.22 & 0.000 \\
\hline Benzaldehyde & GC-MS & 0.07 & 0.02 & 0.18 & 0.025 \\
\hline i-Butanol & GC-MS & 0.08 & 0.02 & 0.20 & 0.014 \\
\hline Methanol & PTR-MS & 2.35 & 0.89 & 6.18 & 0.052 \\
\hline Acetaldehyde & PTR-MS & 1.87 & 0.92 & 4.49 & 0.691 \\
\hline
\end{tabular}

compounds show higher baseline levels during periods I and III. As the life-time of these two compounds exceeds the day, additional imported sources are considered to be responsible for the higher levels registered during the periods where polluted air masses were originating from the continent.

In the third panel, two oxygenated compounds with different lifetimes are presented: acetone (lifetime less than a month taking into account its photolysis and its reaction with $\mathrm{OH}$, Seinfeld and Pandis, 2006) and acetaldehyde (11 $\mathrm{h}$ for an $\mathrm{OH}$ concentration of $1.5 \times 10^{6}$ molecules $\mathrm{cm}^{-3}$, Seinfeld and Pandis, 2006). These two compounds have primary sources mainly of biogenic origin and an important secondary source: the oxidation of non-methane hydrocarbons (NMHC). As shown in Fig. 7, both compounds show relatively lower baseline levels during the oceanic episode (period II) (except for the two maximums observed for the acetone) and higher baseline levels monitored during the continental air masses episodes (periods I and III). The fact that this increase is observed also for acetaldehyde, an oxygenated compound with a relatively short life-time, suggests that during the continental imported air masses, two type of sources are responsible of the high pollution levels: the direct pollution and the imported from over the continent and already processed air masses.

In summary, the examination of the variability of the compounds that have different lifetimes and sources shows that the measurement campaign was impacted during Period II only by local and regional (Paris and its surroundings, socalled "Ile de France") emissions, whereas during the other periods (periods I and III), a significant contribution to the pollution levels in Paris was due to direct import of primary and secondary pollutants emissions that had undergone photochemical aging and mixing during transport to Paris.

The diurnal variation of the main gaseous pollutants in Paris is presented in Appendix B. We have observed that the primary species - CO, NMHC and $\mathrm{NO}$ - show the same daily profile related to their common source, the traffic emissions. They show a minimum value during the night, a first peak in the early morning, a slight decrease in the afternoon and a second peak formed in the evening. This double peak profile 
of the primary pollutants has also been remarked in Paris during spring 2007 (Gros et al., 2011) but also in other city boundaries (de Gouw et al., 2009; Velasco et al., 2007). The main primary emission source in Paris is considered to be the traffic activity which is confirmed by the results of a similar VOC source apportionment exercise performed for the MEGAPOLI campaign (Gros et al., 2012). This study will allow further investigation of the role from local emissions on reactivity.

\subsection{OH reactivity in Paris}

\subsubsection{OH reactivity variability during the MEGAPOLI campaign}

The $\mathrm{OH}$ reactivity measurements were made from 23 January until 13 February. Figure 8 presents the $\mathrm{OH}$ reactivity levels measured: the $2 \mathrm{~min}$ and the $30 \mathrm{~min}$ averaged data series.

$\mathrm{OH}$ reactivity ranged from below the detection limit $\left(3.5 \mathrm{~s}^{-1}\right)$ up to $130 \mathrm{~s}^{-1}$. The median value over the entire campaign was of $33 \mathrm{~s}^{-1}$. Missing points in the data set correspond to periods when instrument check and calibrations were run.

Generally we observed higher $\mathrm{OH}$ reactivity levels measured during the night time compared to daytime levels. This variability of the $\mathrm{OH}$ reactivity is explained by the evolution of the height of the boundary layer, which is lower during the night, and therefore at this time the $\mathrm{OH}$ reactivity is less diluted. This result is in good agreement with the higher level of the $\mathrm{OH}$ reactivity during nighttime than during daytime (except for the double peak due to traffic emissions) measured in other megacities around the world: Nashville, USA (1999) (Kovacs et al., 2003), Houston, USA (2000 and 2006) (Mao et al., 2010), New York (2001) (Ren et al., 2003) and Mexico City (2003) (Shirley et al., 2006).

These same studies showed also that, under the influence of local pollution, the $\mathrm{OH}$ reactivity usually followed the diurnal cycle of the pollutants emitted by traffic emissions: a first peak more or less accentuated, in the early morning (06:30), followed by a slight decrease in the late morning (10:30) and a second peak in the late after-noon and early evening. Nevertheless, we noticed that very few days during this campaign presented the typical diurnal (diel) cycle of a city impacted by traffic emissions. The main reason for this was that the diurnal variability was most of the time overtaken by the impact of long range transport as discussed below.

Regarding the entire MEGAPOLI winter campaign, three contrasting periods have been identified. The origins of the air masses corresponding to these $\mathrm{OH}$ reactivity periods have been previously described (see Sect. 3.1).

The "Period I" started with 26 January, mid-day, and ends on 27, at 21:00 h. The period is characterized by high $\mathrm{OH}$ reactivity levels with a maximum value of $120 \mathrm{~s}^{-1}$ reached on 27 January. The air masses originated from the eastern part

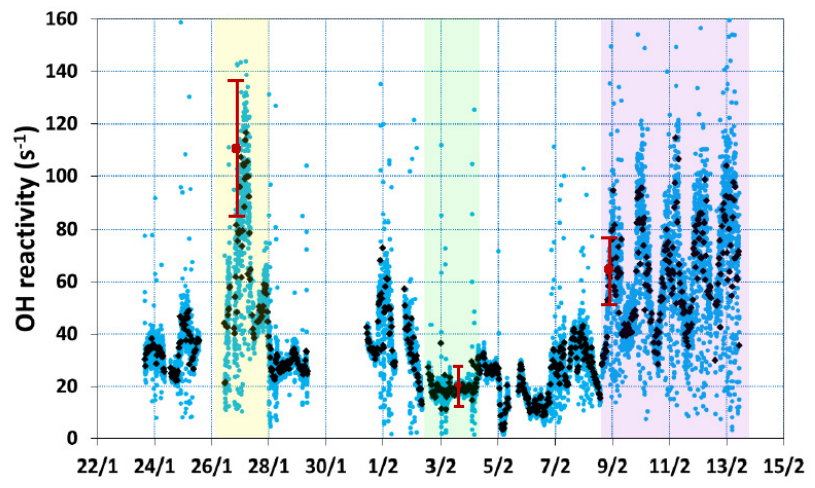

Fig. 8. OH reactivity time series ( 2 min blue dots; 30 min black diamonds). Errors bars corresponding to the estimated uncertainty are given for three levels of $\mathrm{OH}$ reactivity, low $\left(20 \mathrm{~s}^{-1}\right)$, medium $\left(60 \mathrm{~s}^{-1}\right)$ and high $\left(110 \mathrm{~s}^{-1}\right)$.

of the continent and passed over Germany, before reaching Paris. They were therefore charged in pollutants (see discussion from Sect. 3.2.2), and can explain the high $\mathrm{OH}$ reactivity levels registered during "period I".

"Period II" lasted from 2 to 4 February. During this period, low levels of $\mathrm{OH}$ reactivity were registered $\left(20 \mathrm{~s}^{-1}\right)$. This result is consistent with the marine origin of the air masses during this period (see Fig. 6).

"Period III" started with 8 February, 15:00, and lasted until the end of the campaign, 13 February. The $\mathrm{OH}$ reactivity levels reached again very high values of $110 \mathrm{~s}^{-1}$. As for "period I", the air masses mainly originated from the north-eastern part of the continent and the Benelux area. Therefore an additional pollutant source due to the long range transport is considered to be responsible for the higher levels of the measured $\mathrm{OH}$ reactivity

When considering the other time periods not-discussed here (time periods between period I, II and III), the air masses characterized intermediate regimes. The air masses originated either from the central part of France, either from intermediate regimes between the continental and oceanic (see Appendix A). These periods correspond to intermediate $\mathrm{OH}$ reactivity levels.

Table 3 synthetises the mean values of $\mathrm{OH}$ reactivity and the main gaseous pollutants for the three periods previously mentioned.

Generally all the compounds showed lower levels during the marine air mass period (II), than for the continental import periods (I and III), as already described in the previous section. The primary compounds exclusively emitted by local sources (considering their short life-time), here presented by the NO and the xylenes, show levels almost double during "period I" compared to "period III", both continental air masses periods. These high concentrations denote higher local pollution during period I, and implicitly, higher "local" OH reactivity. The other primary compounds presented (CO, benzene and NMHC) showed also the same difference 
Table 3. Mean values of the main pollution compounds measured during period I, II and III.

\begin{tabular}{lrrrrrrrrrr}
\hline & $\begin{array}{r}\text { OH reactivity } \\
\left(\mathrm{s}^{-1}\right)\end{array}$ & $\begin{array}{r}\mathrm{CO} \\
(\mathrm{ppbv})\end{array}$ & $\begin{array}{r}\mathrm{NO} \\
(\mathrm{ppbv})\end{array}$ & $\begin{array}{r}\mathrm{NO}_{2} \\
(\mathrm{ppbv})\end{array}$ & $\begin{array}{r}\text { Benzene } \\
(\mathrm{ppbv})\end{array}$ & $\begin{array}{r}\text { Xylenes } \\
(\mathrm{ppbv})\end{array}$ & $\begin{array}{r}\text { Acetone } \\
(\mathrm{ppbv})\end{array}$ & $\begin{array}{r}\text { NMHC } \\
(\mathrm{ppbv})\end{array}$ & $\begin{array}{r}\text { OVOC } \\
(\mathrm{ppbv})\end{array}$ & $\begin{array}{l}\text { Air } \\
\text { masses }\end{array}$ \\
\hline Period I 26/01-27/01 & 130 & 536 & 24 & 39 & 0.7 & 1.0 & 2.1 & 20.6 & 18.7 & Continental \\
Period II 02/02-04/02 & 20 & 249 & 4 & 28 & 0.2 & 0.5 & 0.7 & 10.1 & 13.1 & Ocean \\
Period III 09/02-13/02 & 110 & 311 & 7 & 27 & 0.3 & 0.6 & 1.0 & 13.2 & 12.4 & Continental \\
\hline
\end{tabular}

between the two continental import periods, but because of their longer life-time, we can conclude that an additional imported source of primary compounds contributes to the total $\mathrm{OH}$ reactivity. Keeping in mind that the $\mathrm{OH}$ reactivity data are associated with an uncertainty of about $24 \%$, some differences can still be seen between these two different periods.

Surprisingly, the sum of the oxygenated VOCs shows higher values during the oceanic air masses period. This result is due to ethanol (which represents $50 \%$ of the OVOCs) and which shows higher level during period II. Biogenic emissions are considered to be the main source of ethanol (Naik et al., 2010) and we note that Lewis et al. (2005) observed also higher OVOCs compared to other species in North Atlantic marine air too.

We conclude that the lowest $\mathrm{OH}$ reactivity levels corresponded to the marine period and were than only impacted by the local and regional pollution. The higher $\mathrm{OH}$ reactivity registered during periods I and III was mainly due to long distance transport.

\subsubsection{OH reactivity levels registered over a local pollution episode}

The previous section suggested that the Paris $\mathrm{OH}$ reactivity larger variability is mainly driven by long range transport when comes to continental air masses. A discussion concerning the diel variation of the $\mathrm{OH}$ reactivity can therefore be done on periods influenced by oceanic air masses, and when only the local pollution is observed. The day of 4 February (Thursday) was chosen because of its mainly oceanic air mass origins (pure oceanic air masses before 09:00, and oceanic and central France after 09:00; see Fig. A1 in the Supplement). We specifically use this day as it was the only one available with marine air mass origins and enough $\mathrm{OH}$ reactivity data. The other days had either larger blank period in the data set due to daily instrumental check, or either did not represent the typical diurnal cycle governed by the morning and evening pollution peaks because they were weekend days. Still, 4 February presented a blank of $2 \mathrm{~h}$ in the data set, from 09:30 to 11:30, which was corresponding to the base line measurements.

Figure 9 presents in the top panel the variation of the $\mathrm{OH}$ reactivity with $\mathrm{NO}$ and in the bottom panel the $\mathrm{OH}$ reactivity plotted with acetone.

For this local pollution episode, NO showed a modified diurnal cycle. Indeed, instead of a double peak normally ob- served during the day and corresponding to the traffic rush hours, on 4 February, NO showed only the morning peak which was doubled. A small peak was observed in the early morning (06:30), followed by a larger one in the late morning, around 11:00. We note that 4 February was a Thursday, when the local public transportation had a strike, probably leading to enhanced use of private vehicle and unusual rush hour time. This conclusion is also sustained by the double peak observed for the same day on other compounds related to traffic emissions: $\mathrm{CO}$ and xylenes.

The first maximum in the NO level corresponding to the morning rush hour is clearly seen on the $\mathrm{OH}$ reactivity as well as the decrease observed around 08:00 and the beginning of the increase observed at 09:00. Unfortunately the second maximum is not captured by the $\mathrm{OH}$ reactivity measurement because of two hours gap in the data set. The good agreement between the $\mathrm{OH}$ reactivity and the $\mathrm{NO}$ denotes that Paris local $\mathrm{OH}$ reactivity is well impacted by traffic related emissions. Nevertheless, in the second part of the day, an increase compared to the morning level (06:00) of the $\mathrm{OH}$ reactivity was observed, increase which was not showed by the NO variability. The second plot of Fig. 9 shows that acetone presents the same change in the concentration level, at the same time of the day. As acetaldehyde shows the same increase of the level measured as acetone, we concluded that for this episode, the in-situ photochemical formation of oxygenated compounds may be responsible of the increase of the $\mathrm{OH}$ reactivity in the afternoon.

\subsection{Missing $\mathrm{OH}$ reactivity in Paris}

The calculated $\mathrm{OH}$ reactivity represents the sum of the product of $\mathrm{OH}$ reactants and their reaction rate coefficient. As previously shown (Kovacs et al., 2003; Di Carlo et al., 2004), comparison between the measured and the calculated $\mathrm{OH}$ reactivity denotes the so-called "missing $\mathrm{OH}$ reactivity" and tests the assumption that all significant $\mathrm{OH}$ reactants have been measured and can be used to infer missing $\mathrm{OH}$ reactants.

Figure 10 presents the total measured $\mathrm{OH}$ reactivity plotted with the calculated $\mathrm{OH}$ reactivity due to the simultaneously measured $\mathrm{OH}$ sink compounds. The VOC species considered for these calculations are presented in Table 2. In addition, results of $\mathrm{CO}, \mathrm{NO}$ and $\mathrm{NO}_{2}$ were also taken in consideration. Because of the winter season, no biogenic emissions were identified (isoprene signal under the detection limit 

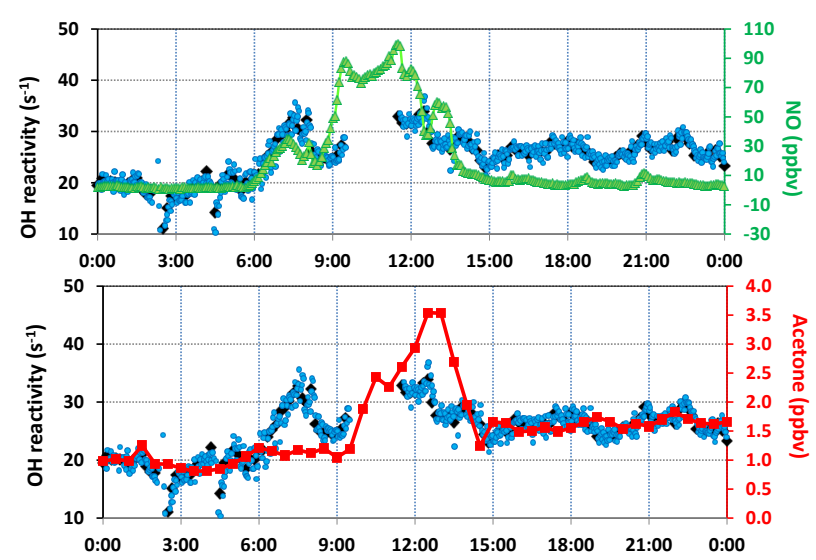

Fig. 9. Daily variability of the $\mathrm{OH}$ reactivity during a local pollution episode: top panel: $\mathrm{OH}$ reactivity time series ( $2 \mathrm{~min}$ blue dots and 10 min black diamonds) and NO time series (5min green triangles). Bottom panel: $\mathrm{OH}$ reactivity time series $(2 \mathrm{~min}$ blue dots and 10 min black diamonds); acetone time series (30 min red squares).

most of the time), and therefore no biogenic compounds were considered. No formaldehyde measurements were made at the LHVP site during the MEGAPOLI winter campaign. Nevertheless, calculations considering high values of formaldehyde were conducted but the equivalent $\mathrm{OH}$ reactivity was not significant (only $2 \mathrm{~s}^{-1}$ for $10 \mathrm{pbbv}$ of formaldehyde, $k_{\mathrm{CH}_{2} \mathrm{O}+\mathrm{OH}}=8.5 \times 10^{-12} \mathrm{~cm}^{3}$ molecule ${ }^{-1} \mathrm{~s}^{-1}$, Atkinson et al., 2006). No formaldehyde reactivity was therefore considered. The $\mathrm{CH}_{4}$ concentration of $1950 \mathrm{ppbv}$ was assumed. Due to the temporal resolution of the instruments, calculated reactivity was performed every $1 \mathrm{~h}$ and $30 \mathrm{~min}$.

When comparing the measured and the calculated $\mathrm{OH}$ reactivity, the calculated level is systematically smaller than the measured one, with the exception of 5 and 8 February, when instrumental interferences were noted. These interferences were mainly due to perturbations of the system when some sporadic "bursts" of pyrrole (a sticky compound) were observed. The median (mean) value of the calculated $\mathrm{OH}$ reactivity over the entire campaign is $16 \mathrm{~s}^{-1}\left(17.5 \mathrm{~s}^{-1}\right)$, while the measured $\mathrm{OH}$ reactivity is double, $33 \mathrm{~s}^{-1}\left(40 \mathrm{~s}^{-1}\right)$.

The breakdown of the total $\mathrm{OH}$ reactivity measured during the entire campaign is presented in Fig. 11. The mean values were taken in consideration for the calculations. The missing $\mathrm{OH}$ reactivity, given by the difference between the measured and the calculated reactivity, is quite high: $54 \%$, showing that when averaged over the entire campaign, more than half of the measured $\mathrm{OH}$ reactivity is not explained. Pie chart $\mathrm{b}$ ) presents the contribution of the different compounds to the calculated $\mathrm{OH}$ reactivity. The main compounds explaining the calculated part of the $\mathrm{OH}$ reactivity are $\mathrm{NO}_{2}(55 \%)$, followed by the sum of NMHCs (15\%), NO and CO (accounting each for $10 \%)$ and finally the sum of OVOCs $(8 \%)$.

Examining now the missing reactivity according to the air mass origins, we note significant difference if the air mass

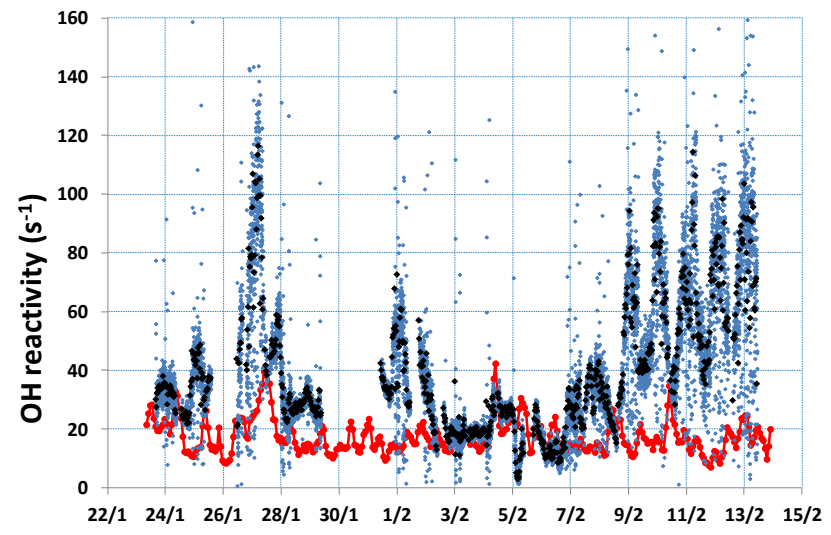

Fig. 10. Calculated (90 min time resolution red curve) versus the measured $\mathrm{OH}$ reactivity ( $2 \mathrm{~min}$ time resolution blue dots, $30 \mathrm{~min}$ average, black diamonds).

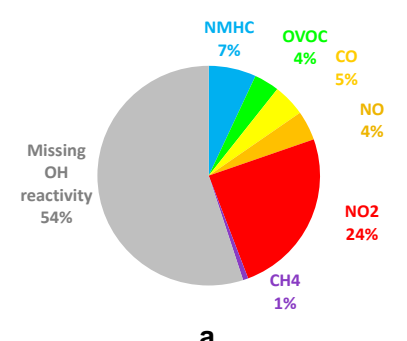

a

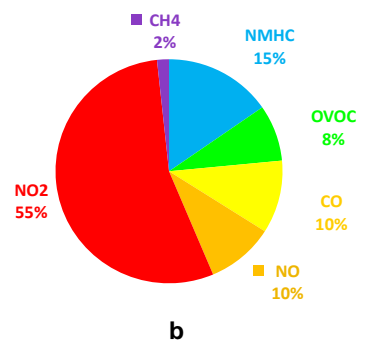

Fig. 11. Breakdown of the (a) total $\mathrm{OH}$ reactivity and (b) calculated $\mathrm{OH}$ reactivity for the entire MEGAPOLI winter campaign. Average total $\mathrm{OH}$ reactivity values were respectively $40.3 \mathrm{~s}^{-1}$ (a) and 17.5 $s^{-1}$ (b).

was of oceanic or of continental origin. Figure 12 presents the enclosed piecharts of the breakdown total $\mathrm{OH}$ reactivity for periods II and III. During the period associated with oceanic air masses and therefore characteristic of the local pollution in Paris, the measured and the calculated $\mathrm{OH}$ reactivity agreed within $12 \%$ (see piechart a), which is within the uncertainty range $( \pm 24 \%)$ of the measured and calculated reactivity. This good agreement points out that during period II, all the main $\mathrm{OH}$ reactive species were measured. As Paris is impacted by traffic emissions, high levels of $\mathrm{NO}_{\mathrm{x}}$ are emitted into the atmosphere. $\mathrm{NO}_{2}$ and $\mathrm{NO}$ explain about $60 \%$ of the total measured $\mathrm{OH}$ reactivity. This large contribution is expected as in urban atmosphere, the main sink of $\mathrm{OH}$ being the formation of the nitric acid $\left(\mathrm{HNO}_{3}\right)$ (Delmas et al., 2005). The $\mathrm{OH}$ reactivity due to the NMHC accounts for $\sim 14 \%$, while the OVOC and the CO contribute with 7 and respectively $8 \%$ to the total $\mathrm{OH}$ reactivity. When considering only the measured VOCs presented in Table 2, among the NMHC, the species that contributed the most to the $\mathrm{OH}$ reactivity were ethene with $13 \%$ and propene with $7.5 \%$. Among the oxygenated VOCs, the acetaldehyde and ethanol 

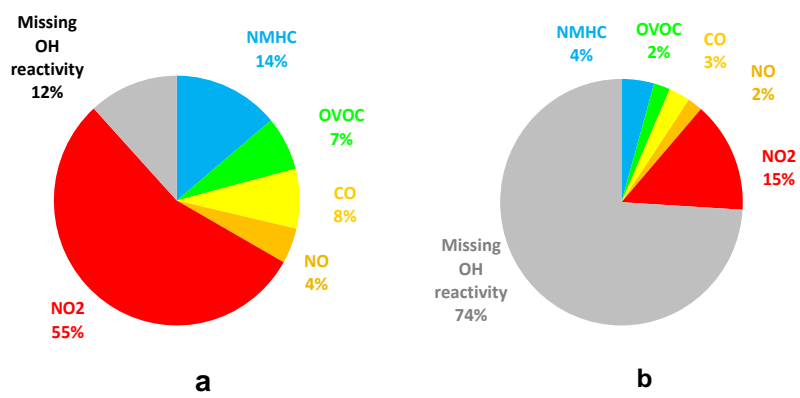

Fig. 12. The Breakdown of the total $\mathrm{OH}$ reactivity for (a) period II and (b) period III. Average total $\mathrm{OH}$ reactivity values were respectively $18.8 \mathrm{~s}^{-1}$ (a) and $63.3 \mathrm{~s}^{-1}$ (b).

contributed with $16 \%$ and respectively $14 \%$ to the $\mathrm{OH}$ reactivity.

We note a very good agreement between the contribution of the different compounds to the total $\mathrm{OH}$ reactivity on the entire campaign (see piechart of Fig. 11) and during the local pollution period from Fig. 12a). This clearly points out that when not under continental pollution plumes, the species which were measured during the MEGAPOLI campaign $\left(\mathrm{CO}, \mathrm{NO}_{\mathrm{x}}\right.$ and list of VOCs from Table 2) characterize correctly the Paris $\mathrm{OH}$ reactivity levels.

Figure $12 \mathrm{~b}$ indicates that during continental import, the measured $\mathrm{OH}$ reactivity was much higher than the calculated value. The missing $\mathrm{OH}$ reactivity was now of $75 \%$. This is a huge value compared to missing $\mathrm{OH}$ reactivities registered in other urban areas (for more details, see Sect. 3.5.3). Calculations indicate that the reactions of $\mathrm{OH}$ with $\mathrm{NO}_{2}$ are the greatest contributors to the total $\mathrm{OH}$ reactivity, and followed by NMHC, CO, OVOCs and NO.

For a better understanding of the variability of the notmeasured $\mathrm{OH}$ reactivity nature, Fig. 13 presents on the top panel the missing $\mathrm{OH}$ reactivity series.

As already predicted, the highest values were registered during the continental air mass imports, while the lowest level was registered under the marine air mass influence. We can conclude that during the local pollution period all of the main $\mathrm{OH}$ reactive species were measured and therefore the $\mathrm{OH}$ reactivity budget can be closed simply by using the already measured compounds. On the contrary, during continental import periods, the non-measured $\mathrm{OH}$ reactive species are considered to be at the origin of the high level of the missing $\mathrm{OH}$ reactivity. Therefore these non-measured species could be: (a) either primary $\mathrm{OH}$ reactive compounds, or (b) secondary species, characteristic of reprocessed air masses. The first suggestion is less probable, if we consider that the most important classes of $\mathrm{OH}$ reactive species, already measured in other studies, were also measured during the MEGAPOLI winter campaign. Furthermore, the good agreement between the measured and calculated $\mathrm{OH}$ reactivity found for "period II" reinforces this conclusion.

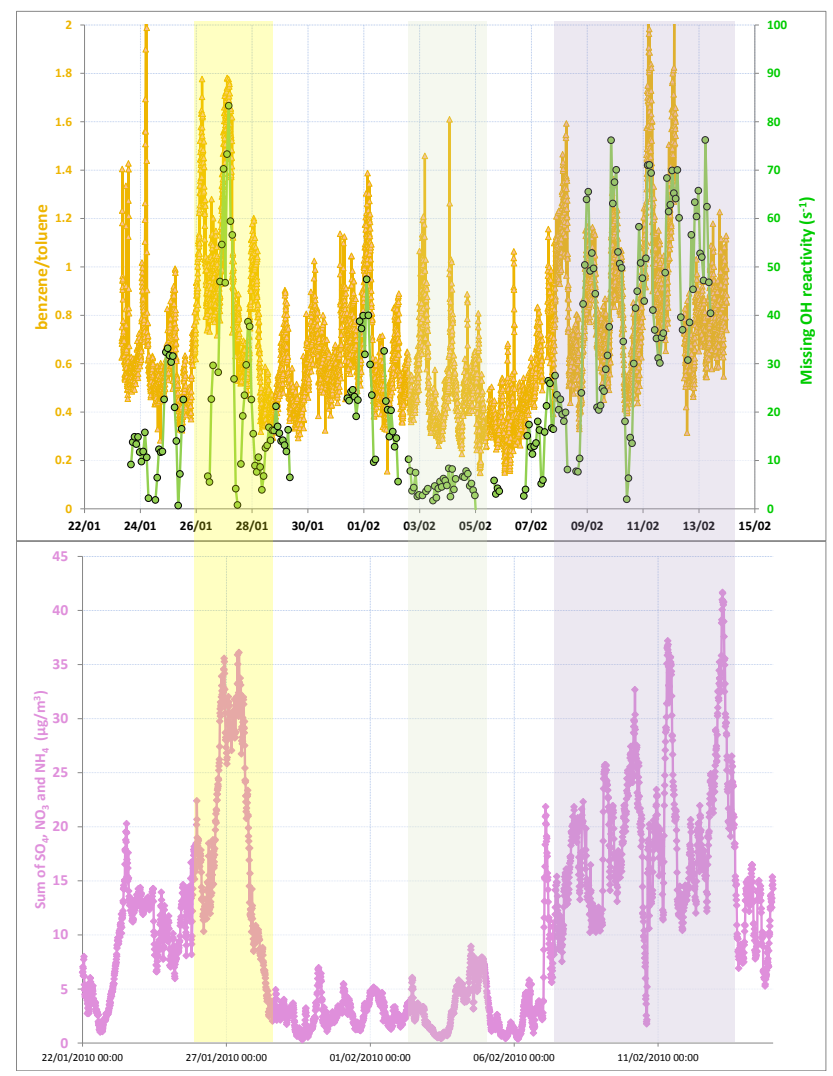

Fig. 13. Top panel: Benzene/Toluene ratio and Missing $\mathrm{OH}$ reactivity; bottom panel: sum of $\mathrm{SO}_{4}, \mathrm{NO}_{3}$ toluene and $\mathrm{NH}_{4}$.

Figure 13a shows as well the evolution of the benzene/toluene ratio. This ratio has been largely used in the literature (following the initial idea of Roberts et al., 1984) to estimate the age of an air mass as these two aromatics compounds are usually issued from the same source whereas their reaction rate with $\mathrm{OH}$ differ by a factor 5 . Therefore a low benzene/toluene ratio will suggest a fresh pollution whereas a higher value will suggest an older pollution. Figure 13 shows that the highest values of the benzene/toluene ratio were observed during period I and III confirming the sampling of air masses impacted by aged pollution at that time. We note that one very high value of the ratio was also observed on 24 January but this was due to a high peak of benzene which may have been caused by a local specific source.

The temporal variability of submicron secondary inorganic salts (ammonium nitrate and ammonium sulphate) measured by AMS is reported in Fig. 13 (second panel). At many locations ammonium nitrate has shown to be correlated with freshly (less-) photochemically aged organic aerosols (OA) whereas ammonium sulphate was more related to regional heavily aged OA (Lanz et al., 2007; Jimenez et al., 2009; Ulbrich et al., 2009). The sum of these two secondary ion components may be then used to infer the role of photochemical processes involved in the formation 
of secondary OA from ambient VOC. Low concentrations of these ions were observed during periods with oceanic air masses whereas significantly higher concentrations were observed during periods I and III which are influenced by continental air masses. These observations are consistent with those reported in Paris during springtime by Sciare et al. (2010) and clearly point to the major influence of photochemically processed continental EU anthropogenic emissions. The good agreement observed in Fig. 13 between the temporal variability of these ions and the missing $\mathrm{OH}$ reactivity strengthens the previous idea that during continental import, the $\mathrm{OH}$ reactivity in Paris is impacted by the nonmeasured oxidized compounds issues of the reprocessing of the air masses (products issued from multi-oxidation of primary compounds).

One striking feature is that the missing reactivity presents the same diurnal cycle as the benzene/toluene ratio and as the inorganic aerosols during period III with values higher during the night. We do not have yet a satisfying explanation for this diurnal cycle but the fact it is presented for three independent parameters (inorganic aerosols, benzene/toluene ratio and missing reactivity) suggest that is was a real phenomenon, maybe linked with the dynamics of the atmosphere.

\subsection{Comparison with $\mathrm{OH}$ reactivity in other urban areas}

\subsubsection{Comparison of $\mathrm{OH}$ reactivity levels with levels measured in other cities around the world}

One should keep in mind that comparing $\mathrm{OH}$ reactivities in different places is a limited exercise as they are by nature a point measurement which can be variable inside a same city. Nevertheless, the measurements performed during the MEGAPOLI campaign took place at a site where well mixed air was sampled and therefore could be considered as representative of Paris background air. Table 4 synthetises the median and the maximum $\mathrm{OH}$ reactivity levels previously measured in other urban areas around the world.

As expected, the lowest median values were noticed in small cities. The median values registered in Nashville (United States), Houston (United States) and Mainz (Germany) hardly exceeded $10 \mathrm{~s}^{-1}$. The highest $\mathrm{OH}$ reactivity value registered corresponded to summer measurements in Tokyo $\left(40 \mathrm{~s}^{-1}\right)$, followed by Mexico City with $33 \mathrm{~s}^{-1}$. Intermediate values were observed for New York City, when for both the winter and the summer campaign, the $\mathrm{OH}$ reactivity was about $20 \mathrm{~s}^{-1}$. When considering the median value of the entire winter campaign, the Paris $\mathrm{OH}$ reactivity was pretty high, of about the same order as for Mexico City, $33 \mathrm{~s}^{-1}$. Nevertheless, this discussion must take into consideration the two contrasting periods identified for the MEGAPOLI winter campaign and which were correlated with different air mass origins (see Sect. 3.3.1). During the local pollution period characterized by the oceanic air masses, the $\mathrm{OH}$ reactivity levels registered were quite low, about $20 \mathrm{~s}^{-1}$, value comparable with values registered in New York for the same period of the year, but also comparable to the values registered in Tokyo during winter. When considering the continental long range transport, the median of the $\mathrm{OH}$ reactivity levels was much higher: $60 \mathrm{~s}^{-1}$.

The maximum $\mathrm{OH}$ reactivity observed during the MEGAPOLI winter campaign was of the same order of magnitude as the maximum measured in Tokyo and New York, but lower than the maximum $\mathrm{OH}$ reactivity measured in Mexico City.

\subsubsection{Analysis of the contributions of different atmospheric constituents to $\mathrm{OH}$ reactivity in different megacities}

Figure 14 presents the contributions from different atmospheric constituents to the calculated $\mathrm{OH}$ reactivity for 5 different urban atmospheres and different periods of the year. For Tokyo values, the data was estimated from Fig. 10 (p. 7879) of the Yoshino et al. (2006) reference. The Mexico City, New York and Houston data were obtained from Mao et al. (2010).

All of the studies presented in Fig. 14 take into consideration measurements of inorganic compounds $\left(\mathrm{CO}, \mathrm{NO}_{\mathrm{x}}\right)$, hydrocarbons (including isoprene), formaldehyde, oxygenated VOCs, but also biogenic emissions, with the exception of Paris, where no formaldehyde and biogenics (because of the winter season) were available. For more details see column "measured species" from Table 2. We can therefore conclude on the pertinence of the further discussion.

The main classes of the compounds actually identified as the main $\mathrm{OH}$ reactivity sinks were taken into consideration in Fig. 14. These are: $\mathrm{CO}, \mathrm{NO}_{\mathrm{x}}$ (sum of $\mathrm{NO}$ and $\mathrm{NO}_{2}$ ), the sum of non-methane hydrocarbons (NMHC), sum of oxygenated VOCs (OVOCs) and the sum of biogenic VOC (BVOCs). Function of the season, the BVOC can be negligible. That is the reason why in Paris, the BVOCs contribution was not quantified. For the same reason, the BVOC contribution in Tokyo was small $(<1 \%)$. As the New York study was performed during summer (see Table 4), the contribution from the BVOC counted for $4 \%$.

The contribution from $\mathrm{CO}$ is very much alike in the five studies (12-15\%), although different seasons are considered. The contribution from the $\mathrm{NO}_{\mathrm{x}}$ exceeds $50 \%$ for Paris, Tokyo and New York cities, showing the large influence of the traffic-related emissions to the calculated $\mathrm{OH}$ reactivity. Still, the Paris $\mathrm{NO}_{\mathrm{x}}$ contribution is the highest registered among the five studies (65\%), strengthening the idea that the local pollution in Paris is mainly impacted by traffic emissions. Mexico City and Houston showed low values of $\mathrm{NO}_{\mathrm{x}}$ (only $23 \%$ and respectively $15 \%$ ), but the contribution from the NMHCs reaches $50 \%$ in both cases. Although Mexico City and New York (comprising their Metropolitan Areas) 
Table 4. Synthesis of $\mathrm{OH}$ reactivity levels measured in other urban atmospheres.

\begin{tabular}{|c|c|c|c|c|c|c|c|}
\hline Urban site & Season, Year & $\begin{array}{l}\text { Employed } \\
\text { technique }\end{array}$ & $\begin{array}{l}\text { Average } \\
\text { /Median }^{\mathrm{a}}\left(\mathrm{s}^{-1}\right)\end{array}$ & $\begin{array}{l}\text { Maximum } \\
\left(\mathrm{s}^{-1}\right)\end{array}$ & $\begin{array}{l}\text { Missing } \mathrm{OH} \\
\text { reactivity }(\%)\end{array}$ & $\begin{array}{l}\text { Measured species } \\
\text { (after Lou et al., 2010) }\end{array}$ & Reference \\
\hline Nashville, USA & Summer 1999 & LIF-H20 & $11,3 \pm 4,8$ & 25 & 31 & SFO & Kovacs et al. (2003) \\
\hline Houston, USA & Autumn 2000 & LIF-H2O & 10 & $12^{\mathrm{c}}$ & $\sim 0^{\mathrm{g}}$ & SFOB & Mao et al. (2010) \\
\hline New York, USA & Summer 2001 & LIF-FAGE & $19 \pm 3$ & 50 & 10 & SFOB & Ren et al. (2003) \\
\hline Mexico City & Spring 2003 & LIF-FAGE & 33 & 200 & - & - & Shirley et al. (2006) \\
\hline Tokyo, Japan & Summer 2003 & LIF P\&P & 40 & 85 & 15 to 30 & SFOB & Sadanaga et al. (2005) \\
\hline New York, USA & Winter 2004 & LIF-FAGE & 20 & 100 & 33 & SF & Ren et al. (2006a) \\
\hline Tokyo, Japan & Winter 2004 & LIF P\&P & $20^{\mathrm{b}}$ & 100 & 5 & SFOB & Yoshino et al. (2006) \\
\hline Mainz, Germany & Summer 2008 & CRM & 10.4 & 18 & - & - & Sinha et al. (2008) \\
\hline Houston, USA & Autumn 2006 & LIF-H20 & $15^{\mathrm{b}}$ & 25 & $\sim 0^{\S}$ & SFOB & Mao et al., (2010b) \\
\hline Paris, France & Winter 2010 & CRM & $33^{\mathrm{d}}\left(19.6^{\mathrm{e}} / 60^{\mathrm{f}}\right)$ & 130 & 12 to 75 & SO & This work \\
\hline
\end{tabular}

LIF- $\mathrm{H}_{2} \mathrm{O}$ Laser Induced Fluorescence Technique - $\mathrm{OH}$ produced by $\mathrm{H}_{2} \mathrm{O}$ photolysis

LIF- P\&P Laser Induced Fluorescence - Pump and Probe Technique

LIF-FAGE Laser Induced Fluorescence - Fluorescence Assay by Gas Expansion

a average was used when median not available

$\mathrm{b}$ approximate values from graphs

c large part of missing data

$\mathrm{d}$ large part of missing datamedian on the entire campaign

e median on the local pollution period

$\mathrm{f}$ median on the continental import period

$\mathrm{g}$ within the measurement and calculated uncertainty

$\mathrm{h}$ measured species that have used for the calculation of the $\mathrm{OH}$ reactivity: $S=$ inorganic compounds $\left(\mathrm{O}_{3}, \mathrm{CO}, \mathrm{NO}_{\mathrm{x}}\right.$, etc) plus hydrocarbons (including isoprene); $F=$ formaldehyde;

$O=$ OVOCs other than formaldehyde; $B=$ biogenic VOCs, other than isoprene.
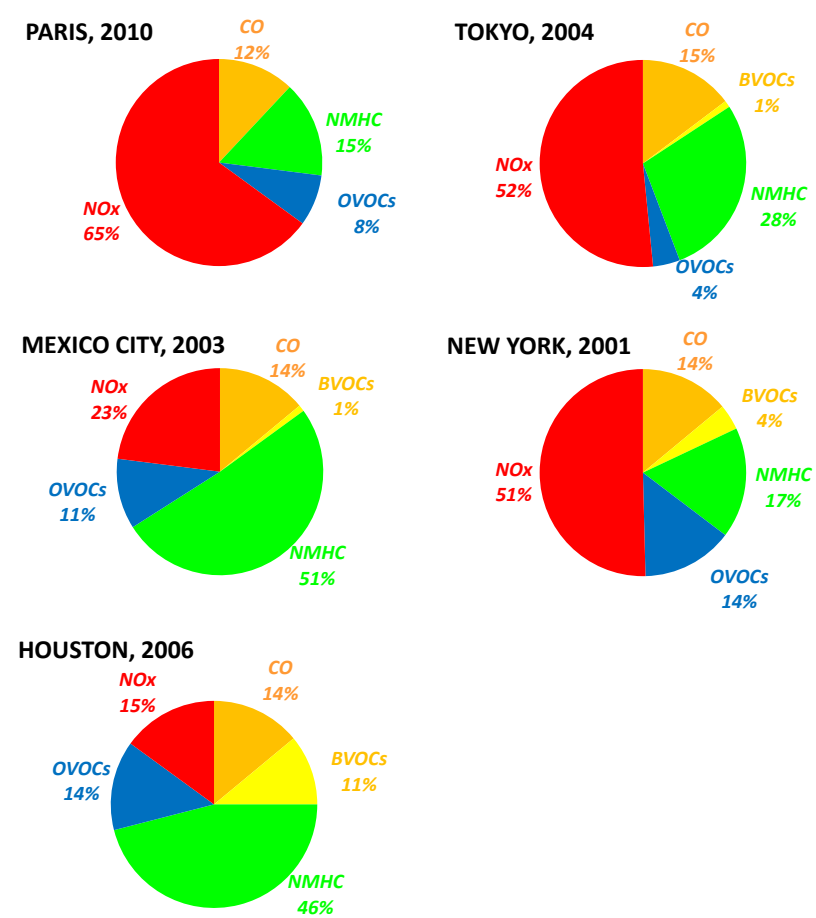

Fig. 14. Contribution of different atmospheric compounds to $\mathrm{OH}$ reactivity in Paris (winter 2010), Tokyo (winter 2004), Mexico City (spring 2003), New York (summer 2001) and Houston (autumn 2006). are comparable in terms of population and size, the NMHC level registered in New York City is rather low because of the more advanced pollution abatement efforts deployed here. Previous study (de Gouw et al., 2006) showed that in Mexico City the high NMHC is due to higher biomass fuel being burnt and therefore explaining the high contribution from the $\mathrm{NMHC}$ to the $\mathrm{OH}$ reactivity. In the case of Houston, Leuchner and Rappenglük (2010) announced high industrial solvent emissions. Higher contributions from aromatics $(15 \%)$ were therefore reported for Houston, compared to only $3.6 \%$ in Paris, $4 \%$ in New York City and $7 \%$ in Mexico City. The contribution to the total $\mathrm{OH}$ reactivity from behalf of the oxygenated VOCs is respectively low, comprised between $4 \%$, for Tokyo, $8 \%$ for Paris and $14 \%$ announced for New York and Houston.

\subsubsection{Missing $\mathrm{OH}$ reactivity in other urban areas}

Table 4 synthetises the percentages of the missing $\mathrm{OH}$ reactivity as previously measured and reported into the literature. Paris results present the highest missing $\mathrm{OH}$ reactivity determined in urban areas (up to $75 \%$ ). This is followed by New York and Tokyo with the values of the missing $\mathrm{OH}$ reactivity of about $30 \%$. A high missing $\mathrm{OH}$ reactivity has been registered also in Nashville, but in this case, the greater measuredthan-calculated $\mathrm{OH}$ reactivity was due to the presence of the non-measured species (no biogenics were measured, although measurements were realized in summer time) during this campaign (Lewis et al., 2000; Kovacs et al., 2003).

$\mathrm{OH}$ reactivity measurements were performed for New York during summer time but also during winter and the 
results showed that the missing $\mathrm{OH}$ reactivity was higher in winter time that in summer. Opposite results have been obtained in Tokyo, when there was almost no missing $\mathrm{OH}$ reactivity during winter. As the suite of simultaneous VOC measurements was inadequate, no missing $\mathrm{OH}$ reactivity levels are available for the Mexico City (Shirley et al., 2006).

The value of the missing $\mathrm{OH}$ reactivity registered in Paris during period II was in good agreement with the winter results in Tokyo and autumn in Houston.

\section{Summary and conclusions}

$\mathrm{OH}$ reactivity measurements using the $\mathrm{CRM}$ method were realized in Paris between 23 January and until 13 February, during the MEGAPOLI winter campaign 2010. As the measurements have been realized in strong NO field (10 to $160 \mathrm{ppbv})$, correction factors were applied to the data set to overcome the NO interference into the setup.

$\mathrm{OH}$ reactivity ranged from below the detection limit $\left(3.5 \mathrm{~s}^{-1}\right)$ up to $130 \mathrm{~s}^{-1}$. The median value registered for the entire campaign was of $33 \mathrm{~s}^{-1}$. As Paris and its surrounding region (Ile de France) are surrounded by a rural area, it was possible to separate continental background influence from oceanic background influence, when discussing the $\mathrm{OH}$ reactivity levels. Considering these two main influences, we could conclude that during the marine air mass origins, the pollution in Paris was mainly due to traffic-related emissions and the measured $\mathrm{OH}$ reactivity level was of $20 \mathrm{~s}^{-1}$, value comparable to values measured in other urban areas (New York and Tokyo). When considering the contribution of different atmospheric constituents to the $\mathrm{OH}$ reactivity in different megacities, two main profiles of urban areas have been identified: one related to traffic emissions, the other one to industrial emissions. Therefore, Paris has the same trafficrelated emission profile as Tokyo and New York, the main compounds that contribute to the calculated $\mathrm{OH}$ reactivity being the $\mathrm{NO}_{\mathrm{x}}$, with more than $50 \%$, followed by NMHCs ( 15 to $28 \%$ ), CO (around $14 \%$ ) and OVOCs (less than 14\%). Mexico City and Houston were identified as cities with industrial profiles, the main contributor to the calculated $\mathrm{OH}$ reactivity being the NMHCs (around 50\%), followed by $\mathrm{NO}_{\mathrm{x}}(15$ to $28 \%)$, OVOCs (11 to $\left.14 \%\right)$ and $\mathrm{CO}(14 \%)$.

During the continental import air masses, an additional imported pollution added to the local one and very high $\mathrm{OH}$ reactivity levels were announced $\left(120 \mathrm{~s}^{-1}\right)$.

Additional measurements and analysis of the variability of a large panel of compounds simultaneously measured within the MEGAPOLI framework $\left(\mathrm{NO}_{\mathrm{x}}, \mathrm{CO}, \mathrm{O}_{3}, \mathrm{NMHCs}\right.$ and OVOCs) pointed out a large part of the missing $\mathrm{OH}$ reactivity. When considering the entire MEGAPOLI campaign, the total missing $\mathrm{OH}$ reactivity was of $54 \%$, showing that when averaged over the entire campaign, more than half of the measured $\mathrm{OH}$ reactivity is not explained. The found value is higher than the values reported in other urban areas and when the maximum missing $\mathrm{OH}$ reactivity was of $33 \%$ (Sadanaga et al., 2004; Ren et al., 2006a). Nevertheless, during the marine air mass influences, the missing $\mathrm{OH}$ reactivity is of only $12 \%$, value comprised within the measurement uncertainties and which has shown that during the local pollution periods, the $\mathrm{OH}$ reactivity budget can be closed only by using the already measured compounds. Still, surprisingly, during the continental imported air masses, $75 \%$ of the measured $\mathrm{OH}$ reactivity could not be explained by the measured species. This percentage was higher than the missing $\mathrm{OH}$ reactivity values registered in other urban areas. The missing $\mathrm{OH}$ reactivity showed a similar variation as longer life-time compounds and photochemically produced aerosol species suggesting that air masses corresponding to continental import were probably loaded in highly oxidized products, probably of anthropogenic origin.

We therefore concluded that levels of missing $\mathrm{OH}$ reactivity of the same magnitude as in forested areas were registered for the first time in an urban area. Still, if for the forested area, previous studies (Di Carlo et al., 2004; Sinha et al., 2010; Kim et al., 2011) identified the biogenic VOCs as mainly responsible of these high levels, in the case of Paris, the non-measured compounds were likely (multi)oxidized compounds issued from processed anthropogenic emissions.

Recently, Kato et al. (2011) proposed a relative rate method using GC-FID detectors to estimate the contribution of the $\mathrm{OH}$ reactivity of unidentified VOCs in the atmosphere of Tokyo (study conducted in spring 2004). They found that the contribution of the unidentified species was about $22 \%$ of that for all the VOCs, and that when taken into consideration they improve the percentage of the missing $\mathrm{OH}$ reactivity that can be explained. Still, the contribution to the total $\mathrm{OH}$ reactivity of the unidentified species using this method is underestimated because species with high polarity or heavy species are being lost during the concentration process.

Considering the vast complexity that the identification and quantification of the unknown $\mathrm{OH}$ reactive species in an urban environment pose for air quality, further studies involving more measurements of secondary compounds are required.

\section{Supplementary material related to this article is available online at: http://www.atmos-chem-phys.net/12/ 9593/2012/acp-12-9593-2012-supplement.pdf.}

Acknowledgements. We would like to thank T. Leonardis and N. Locoge (EMD) for support with GC-MS measurements, B. Temime (LCP) for the PTR-MS measurements and C. Gaimoz (LSCE and now at LISA) for the GC-FID measurements. We would like to thank also the MEGAPOLI field campaign participants and especially M. Beekmann for the coordination of the field campaigns and A. Stohl (NILU) for providing Flexpart results. The research 
leading to these results has received funding from the European Union's Seventh Framework Programme FP/ 2007-2011 within the project MEGAPOLI grant agreement no. 212520. Support from CEA, CNRS, ADEME, ANR-MEGAPOLI are acknowledged.

Edited by: M. Gauss

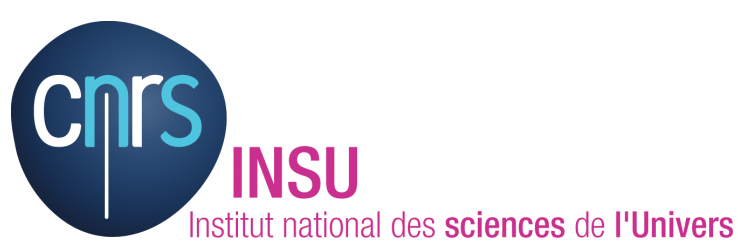

The publication of this article is financed by CNRS-INSU.

\section{References}

Ammann, C., Brunner, A., Spirig, C., and Neftel, A.: Technical note: Water vapour concentration and flux measurements with PTR-MS, Atmos. Chem. Phys., 6, 4643-4651, doi:10.5194/acp6-4643-2006, 2006.

Atkinson, R., Aschmann, S. M., Winer, A. M., and Carter, W. P. L.: Rate Constants for the Gas-Phase Reactions of $\mathrm{OH}$ Radicals and $\mathrm{O}_{3}$ with Pyrrole at 295+/-1k and Atmospheric-Pressure, Atmos. Environ., 18, 2105-2107, 1984.

Atkinson, R., Baulch, D. L., Cox, R. A., Crowley, J. N., Hampson, R. F., Hynes, R. G., Jenkin, M. E., Rossi, M. J., and Troe, J.: Evaluated kinetic and photochemical data for atmospheric chemistry: Volume $\mathrm{I}$ - gas phase reactions of $\mathrm{O}_{\mathrm{x}}, \mathrm{HO}_{\mathrm{x}}, \mathrm{NO}_{\mathrm{x}}$ and $\mathrm{SO}_{\mathrm{x}}$ species, Atmos. Chem. Phys., 4, 1461-1738, doi:10.5194/acp-41461-2004, 2004.

Atkinson, R., Baulch, D. L., Cox, R. A., Crowley, J. N., Hampson, R. F., Hynes, R. G., Jenkin, M. E., Rossi, M. J., Troe, J., and IUPAC Subcommittee: Evaluated kinetic and photochemical data for atmospheric chemistry: Volume II - gas phase reactions of organic species, Atmos. Chem. Phys., 6, 3625-4055, doi:10.5194/acp-6-3625-2006, 2006.

Bavia, M., Bertinelli, F., Taliani, C., and Zauli, C., ElectronicSpectrum of Pyrrole in Vapor and Crystal, Mol. Phys., 31, 479489, 1976.

Canagaratna, M. R., Jayne, J. T., Jimenez, J. L., Allan, J. D., Alfarra, M. R., Zhang, Q., Onasch, T. B., Drewnick, F., Coe, H., Middlebrook, A., Delia, A., Williams, L. R., Trimborn, A. M., Northway, M. J., DeCarlo, P. F., Kolb, C. E., Davidovits, P., and Worsnop, D. R.: Chemical and microphysical characterization of ambient aerosols with the aerodyne aerosol mass spectrometer, Mass Spectrom. Rev., 26, 185-222, doi:10.1002/mas.20115, 2007.

Cronin, B., Nix, M. G. D., Qadiri, R. H., and Ashfold, M. N. R.: High resolution photofragment translational spectroscopy studies of the near ultraviolet photolysis of pyrrole, Phys. Chem. Chem. Phys., 6, 5031-5041, 2004.

Crutzen, P. J.: Global budgets for non-CO2 greenhouse gases, Environ. Monit. and Assess., 31, 1-15, doi:10.1007/bf00547177, 1994.

Day, B. M., Rappengluck, B., Clements, C. B., Tucker, S. C., and Brewer, W. A.: Nocturnal boundary layer characteristics and land breeze development in houston, texas during texaqs ii, Atmos. Environ., 44, 4014-4023, doi:10.1016/j.atmosenv.2009.01.031, 2010.

de Gouw, J. A., Warneke, C., Stohl, A., Wollny, A. G., Brock, C. A., Cooper, O. R., Holloway, J. S., Trainer, M., Fehsenfeld, F. C., Atlas, E. L., Donnelly, S. G., Stroud, V., and Lueb, A.: Volatile Organic Compounds composition of merged and aged forest fire plumes from Alaska and western Canada, J. Geophys. Res.-Atmos., 111, D10303, doi:10.1029/2005jd006175, 2006.

de Gouw, J. A., Welsh-Bon, D., Warneke, C., Kuster, W. C., Alexander, L., Baker, A. K., Beyersdorf, A. J., Blake, D. R., Canagaratna, M., Celada, A. T., Huey, L. G., Junkermann, W., Onasch, T. B., Salcido, A., Sjostedt, S. J., Sullivan, A. P., Tanner, D. J., Vargas, O., Weber, R. J., Worsnop, D. R., Yu, X. Y., and Zaveri, R.: Emission and chemistry of organic carbon in the gas and aerosol phase at a sub-urban site near Mexico City in March 2006 during the MILAGRO study, Atmos. Chem. Phys., 9, 34253442, doi:10.5194/acp-9-3425-2009, 2009.

DeCarlo, P. F., Kimmel, J. R., Trimborn, A., Northway, M. J., Jayne, J. T., Aiken, A. C., Gonin, M., Fuhrer, K., Horvath, T., Docherty, K. S., Worsnop, D. R., and Jimenez, J. L.: Field-deployable, high-resolution, time-of-flight aerosol mass spectrometer, Anal. Chem., 78, 8281-8289, doi:10.1021/ac061249n, 2006.

Delmas, R., Mégie, G. and Peuch, V.-H.: Physique et chimie de l'atmosphère, Ed. Belin, 2005.

Di Carlo, P., Brune, W. H., Martinez, M., Harder, H., Lesher, R., Ren, X. R., Thornberry, T., Carroll, M. A., Young, V., Shepson, P. B., Riemer, D., Apel, E., and Campbell, C.: Missing OH reactivity in a forest: Evidence for unknown reactive biogenic VOCs, Science, 304, 722-725, doi:10.1126/science.1094392, 2004.

Gaimoz, C., Sauvage, S., Gros, V., Herrmann, F., Williams, J., Locoge, N., Perrussel, O., Bonsang, B., d'Argouges, O., SardaEsteve, R., and Sciare, J.: Volatile Organic Compounds sources in paris in spring 2007. Part ii: Source apportionment using positive matrix factorisation, Environ. Chem., 8, 91-103, doi:10.1071/en10067, 2011.

Goldstein, A. H. and Galbally, I. E.: Known and unexplored organic constituents in the earth's atmosphere, Environ. Sci. Technol., 41, 1514-1521, doi:10.1021/es072476p, 2007.

Gros, V., Sciare, J., and Yu, T.: Air-quality measurements in megacities: Focus on gaseous organic and particulate pollutants and comparison between two contrasted cities, Paris and Beijing, Comptes Rendus Geoscience, 339, 764-774, 2007.

Gros, V., Gaimoz, C., Herrmann, F., Custer, T., Williams, J., Bonsang, B., Sauvage, S., Locoge, N., d'Argouges, O., Sarda-Esteve, R., and Sciare, J.: Volatile Organic Compounds sources in Paris in spring 2007. Part i: Qualitative analysis, Environ. Chem., 8, 74-90, doi:10.1071/en10068, 2011.

Gros, V., Marchand, N., Sauvage, S., Perrusel, O., Petetin, H., Lopez, M., Bonnaire, N., Temime, B., Locoge, N., and Bonsang, B.: VOCs source contributions in Paris determined during MEGAPOLI summer and winter campaigns and comparison with the local emission inventory, Atmos. Chem. Phys., in preparation, 2012.

Healy, R. M., Sciare, J., Poulain, L., Kamili, K., Merkel, M., Müller, T., Wiedensohler, A., Eckhardt, S., Stohl, A., Sarda-Estève, R., McGillicuddy, E., O'Connor, I. P., Sodeau, J. R., and Wenger, J. C.: Sources and mixing state of size-resolved elemental carbon particles in a European megacity: Paris, Atmos. Chem. Phys., 12, 
1681-1700, doi:10.5194/acp-12-1681-2012, 2012.

Ingham, T., Goddard, A., Whalley, L. K., Furneaux, K. L., Edwards, P. M., Seal, C. P., Self, D. E., Johnson, G. P., Read, K. A., Lee, J. D., and Heard, D. E.: A flow-tube based laser-induced fluorescence instrument to measure $\mathrm{OH}$ reactivity in the troposphere, Atmos. Meas. Tech., 2, 465-477, doi:10.5194/amt-2-465-2009, 2009.

Jimenez, J. L., Canagaratna, M. R., and Donahue, N. M., et al., Evolution of Organic Aerosols in the Atmosphere, Science, 326, 1525-1529, doi:10.1126/science.1180353, 2009.

Kato, S., Sato, T., and Kajii, Y.: A method to estimate the contribution of unidentified vocs to oh reactivity, Atmos. Environ., 45, 5531-5539, doi:10.1016/j.atmosenv.2011.05.074, 2011.

Kim, S., Guenther, A., Karl, T., and Greenberg, J.: Contributions of primary and secondary biogenic VOC tototal $\mathrm{OH}$ reactivity during the CABINEX (Community Atmosphere-Biosphere INteractions Experiments)-09 field campaign, Atmos. Chem. Phys., 11, 8613-8623, doi:10.5194/acp-11-8613-2011, 2011.

Kovacs, T. A. and Brune, W. H.: Total OH loss rate measurement, J. Atmos. Chem., 39, 105-122, doi:10.1023/a:1010614113786, 2001.

Kovacs, T. A., Brune, W. H., Harder, H., Martinez, M., Simpas, J. B., Frost, G. J., Williams, E., Jobson, T., Stroud, C., Young, V., Fried, A., and Wert, B.: Direct measurements of urban $\mathrm{OH}$ reactivity during Nashville SOS in summer 1999, J. Environ. Monit., 5, 68-74, doi:10.1039/b204339d, 2003.

Lanz, V. A., Alfarra, M. R., Baltensperger, U., Buchmann, B., Hueglin, C., and Prévôt, A. S. H.: Source apportionment of submicron organic aerosols at an urban site by factor analytical modelling of aerosol mass spectra, Atmos. Chem. Phys., 7, 15031522, doi:10.5194/acp-7-1503-2007, 2007.

Leuchner, M. and Rappenglueck, B.: Voc source-receptor relationships in houston during texaqs-ii, Atmos. Environ., 44, 40564067, doi:10.1016/j.atmosenv.2009.02.029, 2010.

Lewis, A. C., Carslaw, N., Marriott, P. J., Kinghorn, R. M., Morrison, P., Lee, A. L., Bartle, K. D., and Pilling, M. J.: A larger pool of ozone-forming carbon compounds in urban atmospheres, Nature, 405, 778-781, doi:10.1038/35015540, 2000.

Lewis, A. C., Hopkins, J. R., Carpenter, L. J., Stanton, J., Read, K. A., and Pilling, M. J.: Sources and sinks of acetone, methanol, and acetaldehyde in North Atlantic marine air, Atmos. Chem. Phys., 5, 1963-1974, doi:10.5194/acp-5-1963-2005, 2005.

Lindinger, W., Hansel, A., and Jordan, A.: On-line monitoring of volatile organic compounds at pptv levels by means of protontransfer-reaction mass spectrometry (PTR-MS) - medical applications, food control and environmental research, Int. J. Mass Spectrom., 173, 191-241, 1998.

Lou, S., Holland, F., Rohrer, F., Lu, K., Bohn, B., Brauers, T., Chang, C.C., Fuchs, H., Häseler, R., Kita, K., Kondo, Y., Li, X., Shao, M., Zeng, L., Wahner, A., Zhang, Y., Wang, W., and Hofzumahaus, A.: Atmospheric $\mathrm{OH}$ reactivities in the Pearl River Delta - China in summer 2006: measurement and model results, Atmos. Chem. Phys., 10, 11243-11260, doi:10.5194/acp-10-11243-2010, 2010.

Mao, J., Ren, X., Brune, W. H., Olson, J. R., Crawford, J. H., Fried, A., Huey, L. G., Cohen, R. C., Heikes, B., Singh, H. B., Blake, D. R., Sachse, G. W., Diskin, G. S., Hall, S. R., and Shetter, R. E.: Airborne measurement of $\mathrm{OH}$ reactivity during INTEX-B, Atmos. Chem. Phys., 9, 163-173, doi:10.5194/acp-9-163-2009,
2009.

Mao, J., Ren, X., Chen, S., Brune, W. H., Chen, Z., Martinez, M., Harder, H., Lefer, B., Rappenglueck, B., Flynn, J., and Leuchner, M.: Atmospheric oxidation capacity in the summer of Houston 2006: Comparison with summer measurements in other metropolitan studies, Atmos. Environ., 44, 4107-4115, doi:10.1016/j.atmosenv.2009.01.013, 2010.

Michoud, V., Kukui, A., Camredon, M., Colomb, A., Borbon, A., Miet, K., Aumont, B., Beekmann, M., Durand-Jolibois, R., Perrier, S., Zapf, P., Siour, G., Ait-Helal, W., Locoge, N., Sauvage, S., Gros, V., Afif, C., Furger, M., Ancellet, G., and Doussin, J. F.: Radical budget analysis in a suburban European site during the MEGAPOLI summer field campaign, Atmos. Chem. Phys. Discuss., 12, 15883-15943, doi:10.5194/acpd-12-15883-2012, 2012.

Naik, V., Fiore, A. M., Horowitz, L. W., Singh, H. B., Wiedinmyer, C., Guenther, A., de Gouw, J. A., Millet, D. B., Goldan, P. D., Kuster, W. C., and Goldstein, A.: Observational constraints on the global atmospheric budget of ethanol, Atmos. Chem. Phys., 10, 5361-5370, doi:10.5194/acp-10-5361-2010, 2010.

Nölscher, A. C., Sinha, V., Bockisch, S., Klüpfel, T., and Williams, J.: A new method for total $\mathrm{OH}$ reactivity measurements using a fast Gas Chromatographic Photo-Ionization Detector (GC-PID), Atmos. Meas. Tech. Discuss., 5, 3575-3609, doi:10.5194/amtd5-3575-2012, 2012.

Ren, X. R., Harder, H., Martinez, M., Lesher, R. L., Oliger, A., Shirley, T., Adams, J., Simpas, J. B., and Brune, W. H.: $\mathrm{HO}_{\mathrm{x}}$ concentrations and $\mathrm{OH}$ reactivity observations in New York city during PMTACS-NY 2001, Atmos. Environ., 37, 3627-3637, doi:10.1016/s1352-2310(03)00460-6, 2003.

Ren, X., Brune, W. H., Mao, J., Mitchell, M. J., Lesher, R. L., Simpas, J. B., Metcalf, A. R., Schwab, J. J., Cai, C., Li, Y., Demerjian, K. L., Felton, H. D., Boynton, G., Adams, A., Perry, J., He, Y., Zhou, X., and Hou, J.: Behavior of $\mathrm{OH}$ and $\mathrm{HO}_{2}$ in the winter atmosphere in New York city, Atmos. Environ., 40, S252-S263, doi:10.1016/j.atmosenv.2005.11.073, 2006a.

Ren, X., Brune, W. H., Oliger, A., Metcalf, A. R., Simpas, J. B., Shirley, T., Schwab, J. J., Bai, C., Roychowdhury, U., Li, Y., Cai, C., Demerjian, K. L., He, Y., Zhou, X., Gao, H., and Hou, J.: $\mathrm{OH}, \mathrm{HO}_{2}$, and OHreactivity during the PMTACSNY whiteface mountain 2002 campaign: Observations and model comparison, J. Geophys. Res.-Atmos., 111, D10s03, doi:10.1029/2005jd006126, 2006b.

Roberts, J. M., Fehsenfeld, F. C., Liu, S. C.; Bollinger, M. J., Hahn, C., Albritton, D. L., and Sievers, R. E.: Measurements of aromatic hydrocarbon ratios and $\mathrm{NO}_{\mathrm{x}}$ concentrations in the rural troposphere - observation of air-mass photochemical aging and $\mathrm{NO}_{\mathrm{X}}$ removal, Atmos. Environ., 18, 2421-2432, 1984.

Roukos, J., Plaisance, H., Leonardis, T., Bates, M., and Locoge, N.: Development and validation of an automated monitoring system for oxygenated volatile organic compounds and nitrile compounds in ambient air, Journal of Chromatography A, 1216, 8642-8651, doi:10.1016/j.chroma.2009.10.018, 2009.

Sadanaga, Y., Yoshino, A., Kato, S., Yoshioka, A., Watanabe, K., Miyakawa, Y., Hayashi, I., Ichikawa, M., Matsumoto, J., Nishiyama, A., Akiyama, N., Kanaya, Y., and Kajii, Y.: The importance of $\mathrm{NO}_{2}$ and volatile organic compounds in the urban air from the viewpoint of the $\mathrm{OH}$ reactivity, Geophys. Res. Lett., 31, L08102, doi:10.1029/2004g1019661, 2004. 
Sadanaga, Y., Yoshino, A., Kato, S., and Kajii, Y.: Measurements of oh reactivity and photochemical ozone production in the urban atmosphere, Environ. Sci. Technol. 39, 8847-8852, doi:10.1021/es049457p, 2005.

Sadanaga, Y., Kondo, S., Hashimoto, K., and Kajii, Y.: Measurement of the rate coefficient for the $\mathrm{OH}+\mathrm{NO}_{2}$ reaction under the atmospheric pressure: Its humidity dependence, Chem. Phys. Lett., 419, 474-478, doi:10.1016/j.cplett.2005.12.026, 2006.

Sciare, J., d'Argouges, O., Zhang, Q. J., Sarda-Estève, R., Gaimoz, C., Gros, V., Beekmann, M., and Sanchez, O.: Comparison between simulated and observed chemical composition of fine aerosols in Paris (France) during springtime: contribution of regional versus continental emissions, Atmos. Chem. Phys., 10, 11987-12004, doi:10.5194/acp-10-11987-2010, 2010.

Seinfeld, J. H. and Pandis, S. N.: Atmospheric chemistry and physics: From air pollution to climate change, Ed. WileyInterscience, 2006.

Shirley, T. R., Brune, W. H., Ren, X., Mao, J., Lesher, R., Cardenas, B., Volkamer, R., Molina, L. T., Molina, M. J., Lamb, B., Velasco, E., Jobson, T., and Alexander, M.: Atmospheric oxidation in the Mexico City Metropolitan Area (MCMA) during April 2003, Atmos. Chem. Phys., 6, 2753-2765, doi:10.5194/acp-62753-2006, 2006.

Sinha, V., Williams, J., Crowley, J. N., and Lelieveld, J.: The Comparative Reactivity Method - a new tool to measure total $\mathrm{OH}$ Reactivity in ambient air, Atmos. Chem. Phys., 8, 2213-2227, doi:10.5194/acp-8-2213-2008, 2008.

Sinha, V., Custer, T. G., Kluepfel, T., and Williams, J.: The effect of relative humidity on the detection of pyrrole by PTR-MS for OH reactivity measurements, Int. J. Mass Spectrom., 282, 108-111, doi:10.1016/j.ijms.2009.02.019, 2009.

Sinha, V., Williams, J., Lelieveld, J., Ruuskanen, T. M., Kajos, M. K., Patokoski, J., Hellen, H., Hakola, H., Mogensen, D., Boy, M., Rinne, J., and Kulmala, M.: OH reactivity measurements within a boreal forest: Evidence for unknown reactive emissions, Environ. Sci. Technol., 44, 6614-6620, doi:10.1021/es101780b, 2010.

Sinha, V., Williams, J., Diesch, J. M., Drewnick, F., Martinez, M., Harder, H., Regelin, E., Kubistin, D., Bozem, H., HosaynaliBeygi, Z., Fischer, H., Andrés-Hernández, M. D., Kartal, D., Adame, J. A., and Lelieveld, J.: Constraints on instantaneous ozone production rates and regimes during DOMINO derived using in-situ $\mathrm{OH}$ reactivity measurements, Atmos. Chem. Phys., 12, 7269-7283, doi:10.5194/acp-12-7269-2012, 2012.
Stohl, A., Forster, C., Frank, A., Seibert, P., and Wotawa, G.: Technical note: The Lagrangian particle dispersion model FLEXPART version 6.2, Atmos. Chem. Phys., 5, 2461-2474, doi:10.5194/acp-5-2461-2005, 2005.

Tuch, T. M., Haudek, A., Müller, T., Nowak, A., Wex, H., and Wiedensohler, A.: Design and performance of an automatic regenerating adsorption aerosol dryer for continuous operation at monitoring sites, Atmos. Meas. Tech., 2, 417-422, doi:10.5194/amt-2-417-2009, 2009.

Ulbrich, I. M., Canagaratna, M. R., Zhang, Q., Worsnop, D. R., and Jimenez, J. L.: Interpretation of organic components from Positive Matrix Factorization of aerosol mass spectrometric data, Atmos. Chem. Phys., 9, 2891-2918, doi:10.5194/acp-9-2891-2009, 2009.

Vardoulakis, S., Gonzalez-Flesca, N., and Fisher, B. E. A.: Assessment of traffic-related air pollution in two street canyons in paris: Implications for exposure studies, Atmos. Environ., 36, 10251039, 2002.

Velasco, E., Lamb, B., Westberg, H., Allwine, E., Sosa, G., ArriagaColina, J. L., Jobson, B. T., Alexander, M. L., Prazeller, P., Knighton, W. B., Rogers, T. M., Grutter, M., Herndon, S. C., Kolb, C. E., Zavala, M., de Foy, B., Volkamer, R., Molina, L. T., and Molina, M. J.: Distribution, magnitudes, reactivities, ratios and diurnal patterns of volatile organic compounds in the Valley of Mexico during the MCMA 2002 \& 2003 field campaigns, Atmos. Chem. Phys., 7, 329-353, doi:10.5194/acp-7-329-2007, 2007.

Xu, X., Stee, L. L. P., Williams, J, Beens, J., Adahchour, M., Vreuls, R. J. J., Brinkman, U. A., and Lelieveld, J.: Comprehensive twodimensional gas chromatography $(\mathrm{GC} \times \mathrm{GC})$ measurements of volatile organic compounds in the atmosphere, Atmos. Chem. Phys., 3, 665-682, doi:10.5194/acp-3-665-2003, 2003.

Yoshino, A., Sadanaga, Y., Watanabe, K., Kato, S., Miyakawa, Y., Matsumoto, J., and Kajii, Y.: Measurement of total OH reactivity by laser-induced pump and probe technique - comprehensive observations in the urban atmosphere of Tokyo, Atmos. Environ., 40, 7869-7881, doi:10.1016/j.atmosenv.2006.07.023, 2006. 